\title{
GEOTHERMAL DEVELOPMENT OF THE SALTON TROUGH, CALIFORNIA AND MEXICO
}

Editors:

T. D. Palmer

J. H. Howard

D. P. Lande

April 1, 1975

Prepared for U.S. Energy Research \& Development

Administration under contract No. W-7405-Eng-48

\section{LAWRENCE LUERMORE}
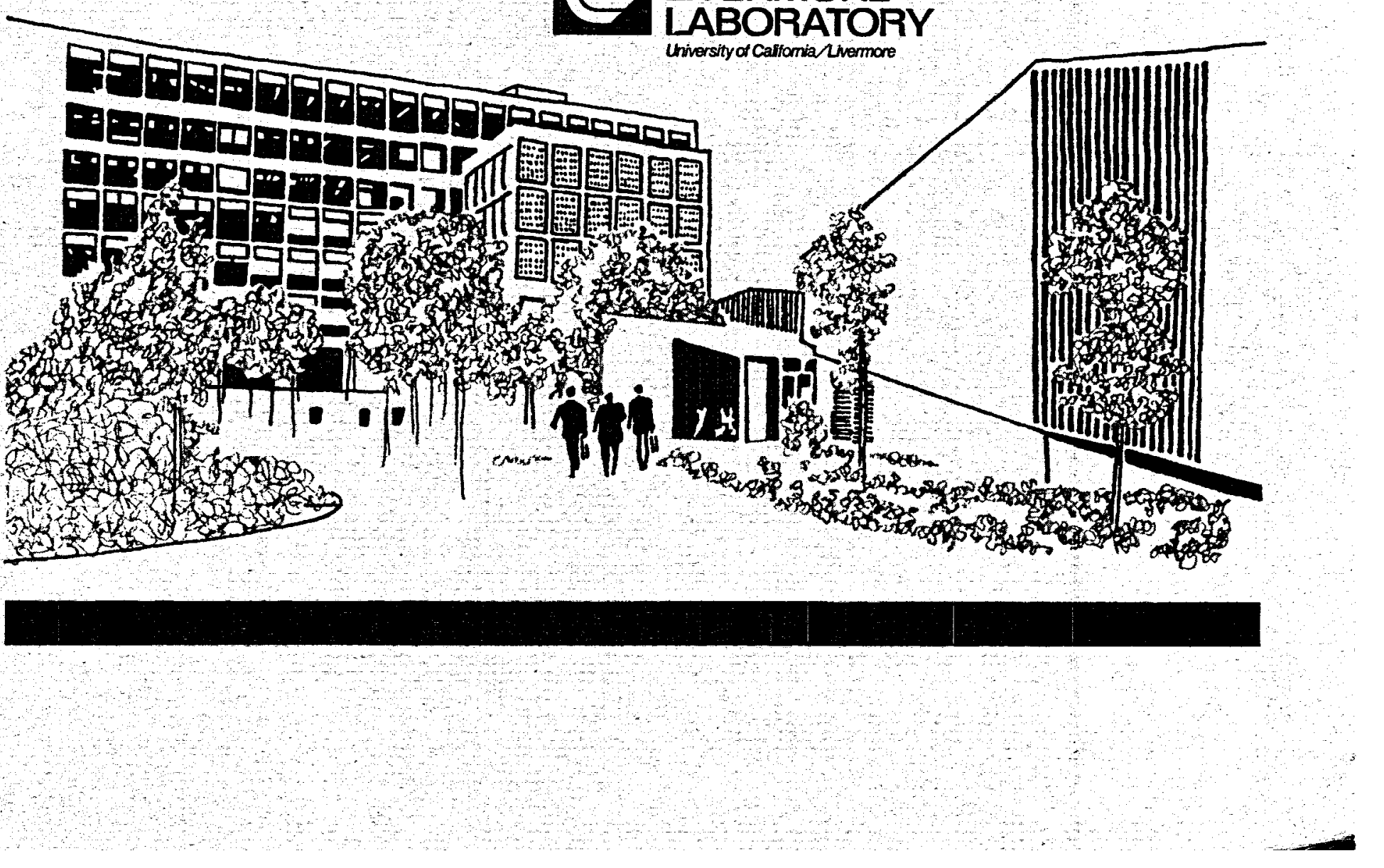


\section{DISCLAIMER}

This report was prepared as an account of work sponsored by an agency of the United States Government. Neither the United States Government nor any agency Thereof, nor any of their employees, makes any warranty, express or implied, or assumes any legal liability or responsibility for the accuracy, completeness, or usefulness of any information, apparatus, product, or process disclosed, or represents that its use would not infringe privately owned rights. Reference herein to any specific commercial product, process, or service by trade name, trademark, manufacturer, or otherwise does not necessarily constitute or imply its endorsement, recommendation, or favoring by the United States Government or any agency thereof. The views and opinions of authors expressed herein do not necessarily state or reflect those of the United States Government or any agency thereof. 


\section{DISCLAIMER}

Portions of this document may be illegible in electronic image products. Images are produced from the best available original document. 


\section{NOTICE}

st This report was prepared as an account of work sponsored by the United States Government. Neither the United States nor the United States Energy Research. \& Development Administration, nor any of their employees, nor any of their contractors subcontractors or their employees makes any warranty, express or implied, or assumes any legal warranty, express or implied, or assumes any legal completeness or usefulness of any information apparatus, product or process disclosed, or represents that its use would not infringe privately-owned rights."

Printed in the United States of America Available from

National Technical Information Service U.S. Department of Commerce 5285 Port Royal Road

Springfield, Virginia 22151

Price: Printed Copy $\$ *$; Microfiche $\$ 2.25$

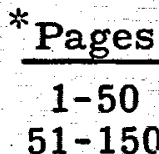

$151-325$

$326-500$

501-1000
NTIS

Selling Price

$\$ 4.00$

$\$ 5.45$

$\$ 7.60$

$\$ 10.60$

$\$ 13.60$ 
TID-4500, UC- 13

Nonnuclear Energy Sources

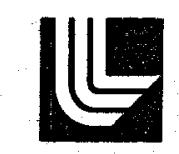

\title{
LAWRENCE LNERMORE LABORATORY
}

university of Cafifornia/Livermore, Calfitomia/ 94550

UCR L-51775

\section{GEOTHERMAL DEVELOPMENT OF THE SALTON TROUGH, CALIFORNIA AND MEXICO}

\author{
Editors: \\ T. D. Palmer \\ J. H. Howard \\ D.P. Lande
}

MS. date: April 1, 1975

\footnotetext{
"Permanent address: Division of Oil and Gas, State of California

5199 E. Pacific Coast Hwy., Long Beach, CA 90804
} 


\section{Contents}

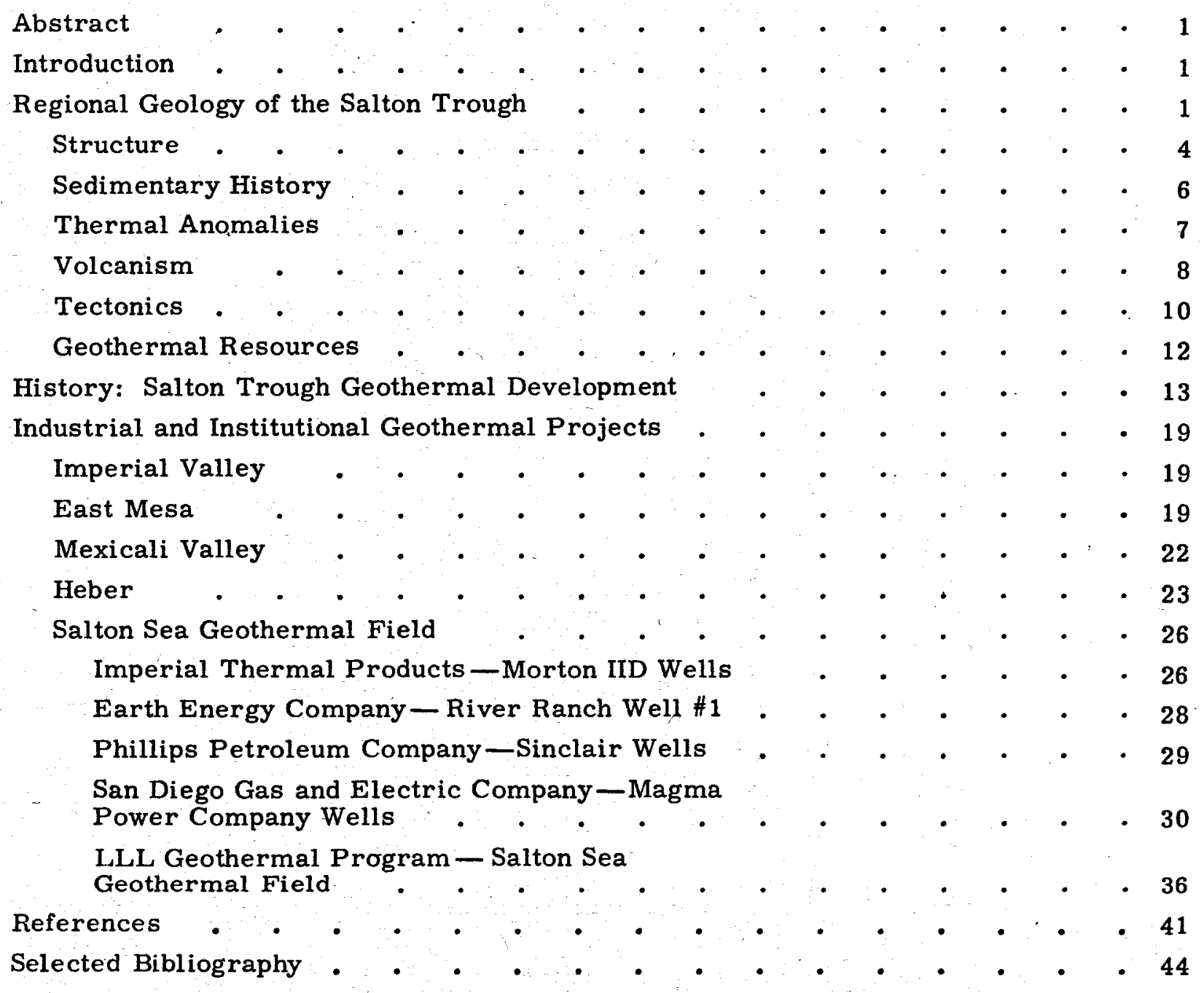




\section{GEOTHERMAL DEVELOPMENT OF THE SALTON TROUGH, CALIFORNIA AND MEXICO}

\section{Abstract}

A geological description is given of the Salton Trough followed by a chronological history of attempts to exploit the area's geothermal resources. In addi- tion, detailed descriptions are given of all ongoing geothermal projects in the area and the organizations conducting them.

\section{Introduction *}

This report has been prepared for use by the Second United Nations Geothermal Symposium to be held in San Francisco, California, 20-29 May 1975. The University of California, in association with other public and private agencies, is supporting the United Nations Secretariat in the organization and presentation of this symposium. The goal of the meeting is to foster the exchange of information and experience among countries involved in geothermal research. Toward this end, this report presents information on geothermal developments in the Salton Trough, California and Mexico (Figs. 1 and 2), one of North America's largest geothermal resource areas. The Salton Trough now has one operating geothermal power plant at Cerro Prieto, Mexico, and intense research and development efforts are underway to establish additional plants.
This paper discusses these activities, including the problems and progress of past and present research projects, and presents a geological description of the region.

This report was prepared by the Lawrence Livermore Laboratory from the contributions of the following individuals: W. A. Elders, University of California, Riverside; M. K. Fulcher, U.S. Bureau of Reclamation; Ing. J. Guiza, Comision Federal de Electricidad; D. R. Butler, Chevron Oil Company; T. C. Hinrichs, Magma Power Company; B. W. Berthelot, Phillips Petroleum Company;

A. L. Austin and A. W. Lundberg, Lawrence Livermore Laboratory; and the editors of this paper. Logistics and support activities for this report were provided by F. J. Warren and W. J، Herlihy of Lawrence Livermore Laboratory.

\section{Regional Geology of the Salton Trough $\uparrow$}

The water-dominated geothermal fields in the Imperial and Mexicali Valleys of Southern California, U.S.A., and Northern
Baja California, Mexico, occur within the physiographic province known as the Salton Basin. This basin, which forms the

* Thomas D. Palmer, Earth Sciences Division, Lawrence Livermore Laboratory, Livermore, CA.

$f_{\text {Wilfred A. Elders, Dept. of Earth Sciences, University of California (Riverside) }}$ Riverside, CA (Ref. IGPP-UCR-75-6). 


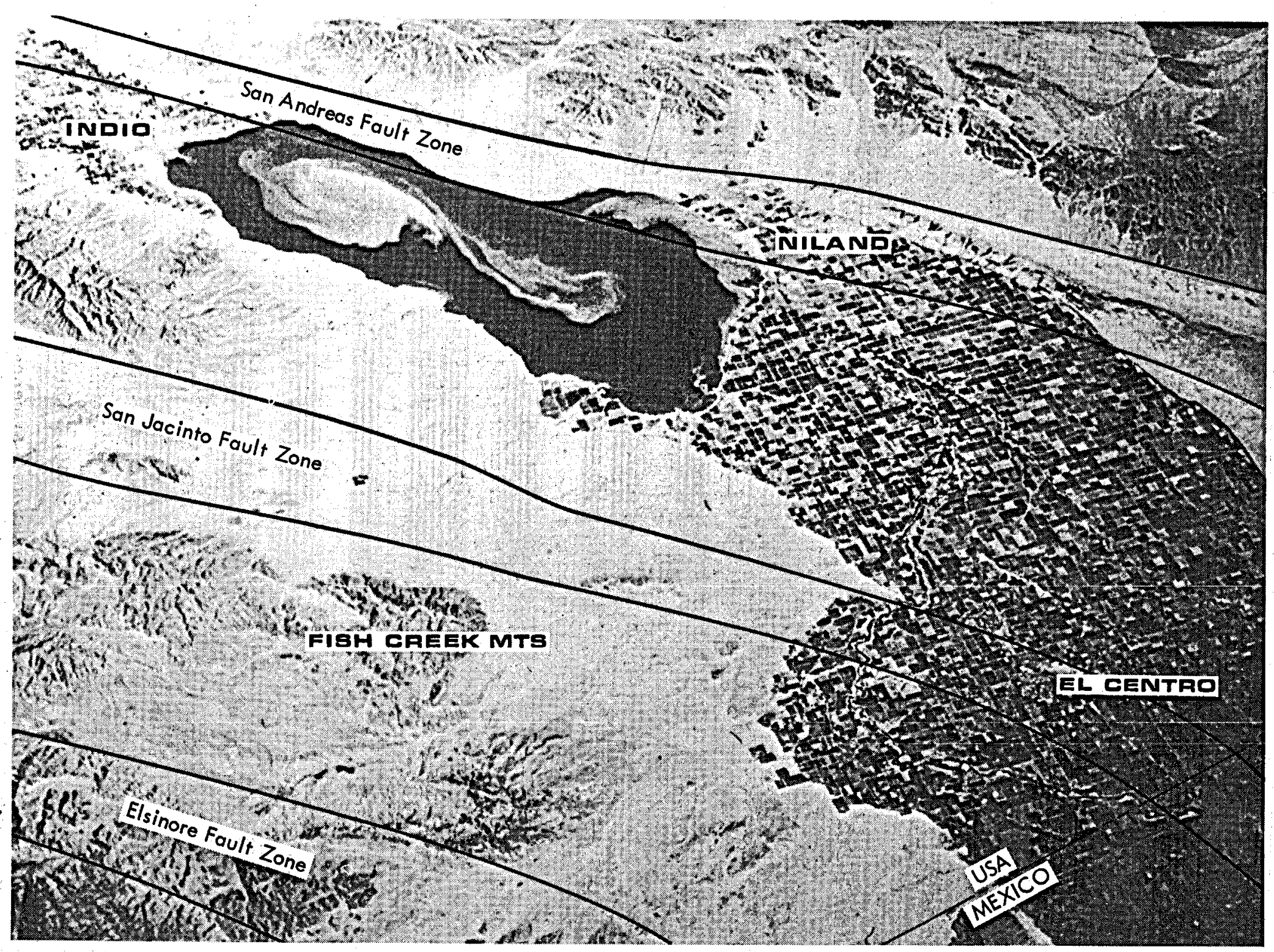

Fig. 1. Salton Sea and Salton Trough as seen from orbiting Gemini V spacecraft, August 1965. Coachella Valley upper left, Imperial and Mexicali Valleys lower right. (Photo courtesy of NASA.) 


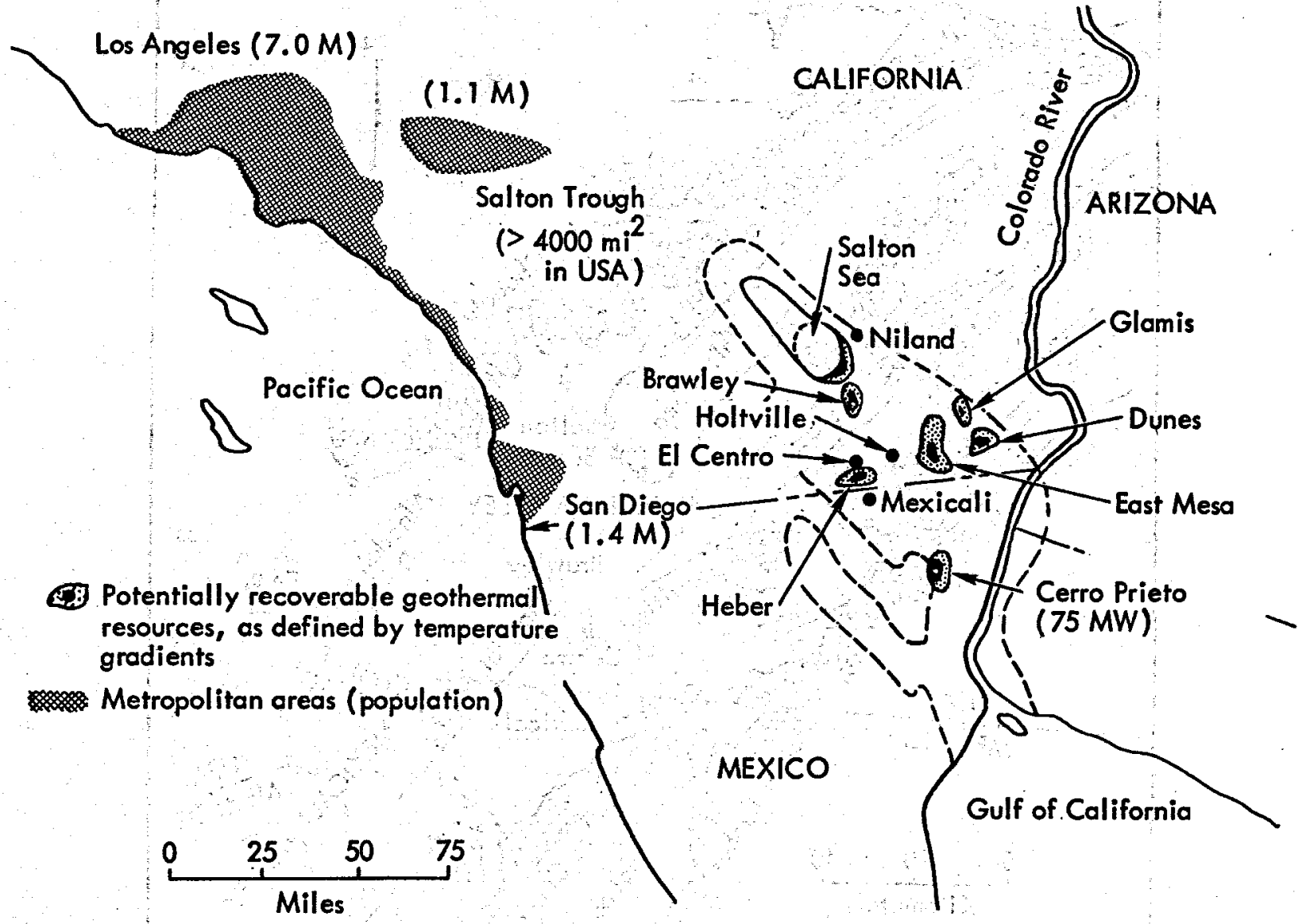

Fig. 2. Salton Trough geothermal province and known geothermal resource areas $\left(\sim 400 \mathrm{mi}^{2}\right.$ KGRA).

northern part of the Colorado River delta (Fig. 3), is the surface expression of a deep, sediment-filled, structural trough, or rift valley, called the Salton Trough. It is the landward extension of the Gulf of California northwards into North America. The overall structure of the trough is apparently controlled by the numerous strike-slip faults related to the San Andreas fault system (Fig. 4).

The Gulf of California and the Salton Trough are areas of rapid tectonic deformation, where patterns of high heat flow and seismicity, together with patterns of sedimentation and volcanicity, reflect a transition from the divergent plate boundary of the East Pacific Rise to the transform boundary represented by the San Andreas fault system (Wilson, 1965; Larson et al., 1968; Atwater, 1970; Elders, et al., 1972; and Moore, 1973).

Paleontological evidence suggests that the Gulf of California has existed as a morphotectonic depression for the last 15 million years. Marine foraminifera of late Miocene to early Pliocene age attest to the existence of deep water in the Gulf from 11 to 8 million years ago (Ingle, in Elders and Biehler, 1975). Marine geophysical surveys have revealed numerous elongate topographic depressions in the Gulf floor (Fig. 4) bounded by seismically active faults. These closed basins have heat flows several times the crustal 


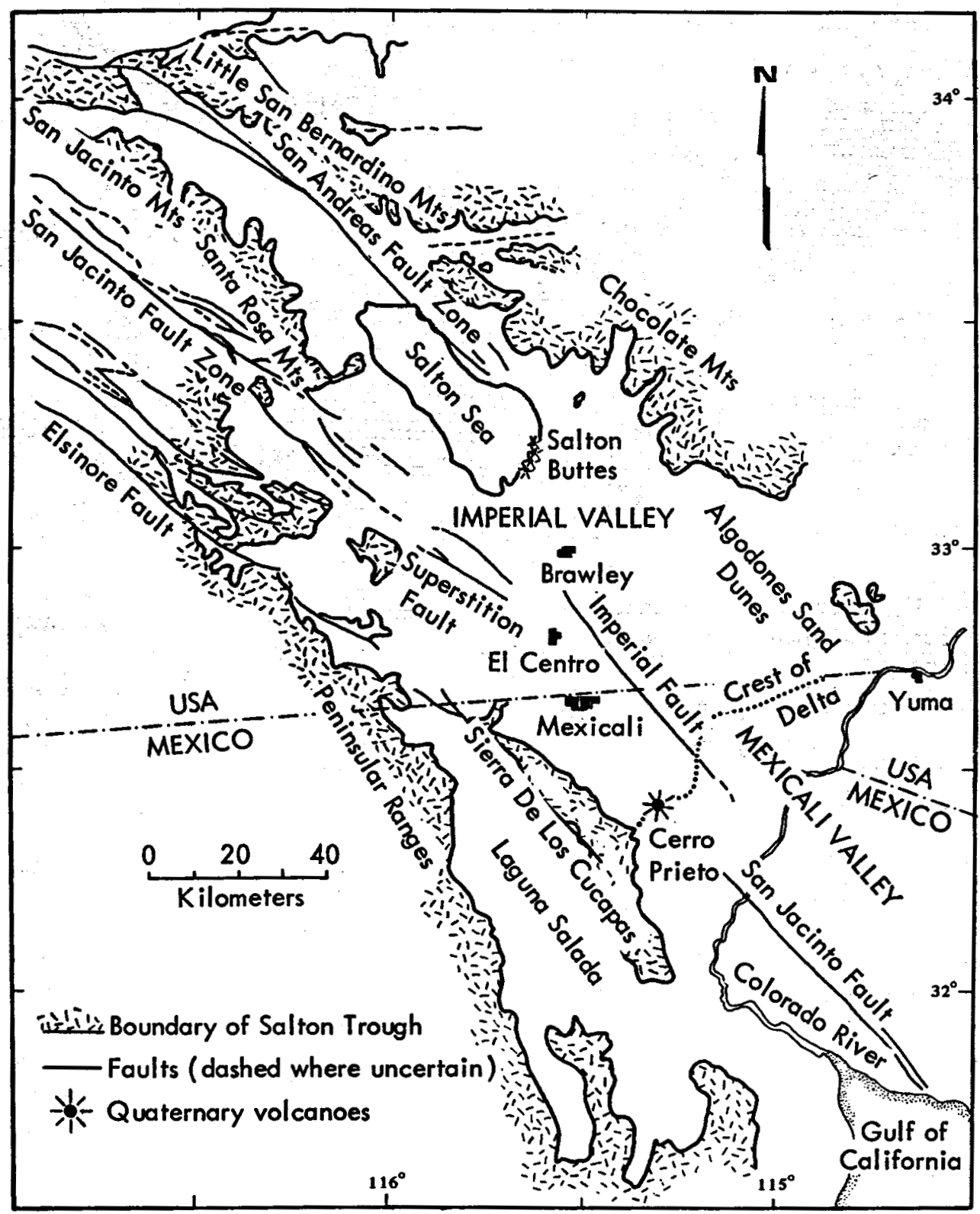

Fig. 3. Salton Trough index map showing Imperial and Mexicali Valleys.

average, have positive gravity anomalies of up to $+80 \mathrm{mgal}$, and appear to have been produced by active spreading between en echelon fault segments (Moore, 1973). At the mouth of the Gulf, south of the Tamayo fracture zone, spreading on the East Pacific Rise has proceeded at $6 \mathrm{~cm}$ a year for the last 4.5 million years (Larson, 1972). The development of the deep basins also appears to date from that time.

\section{STRUCTURE}

In gross structure and size, the Salton Trough is similar to the deep, closed, marine basins found in the Gulf of California. However, it is partially filled 
with a vast accumulation of mainly continental sedimentary rocks. It is a complex rift valley bordered by mountains consisting of Mesozoic, and older, granitic and metamorphic rocks, with some Tertiary volcanic rocks. It has steep, stepfaulted margins and a broad, relatively flat basement floor beneath a cover of sedimentary rocks 6 to $7 \mathrm{~km}$ thick in the center of the Imperial Valley (Elders, et al.; 1972). These rocks are transected by three major fault systems, which trend northwest-southeast: the San Andreas, San Jacinto, and Elsinore fault zones (Fig. 3). Numerous subsidiary blocks and basins are aligned along these major strike-slip faults.

Seismic activity along these faults makes the Salton Trough one of the most earthquake-prone areas in North America. There have been more than 12 earthquakes of magnitude greater than 6.0 (Richter scale) in the area this century. Early in 1975 , an earthquake swarm, centered

Fig. 4. Gross tectonic environment of the Salton Trough. The Pacific Coast of North America is dominated by transform fault systems, which connect the spreading centers of the East Pacific Rise to those of the Gorda Ridge. Also shown are pull-apart basins between en echelon fault segments in the Gulf of California. Oceanic fracture zones (FZ) and continental faults (F) are solid black lines, dashed where uncertain. Other abbreviations: SAF = San Andreas Fault; EF = Elsinore Fault; SJF = San Jacinto Fault; ABF = Aqua Blanca Fault; SRF = Santa Rosalia Fault; W = Wagner Basin; $D$ = Delfin Basin;

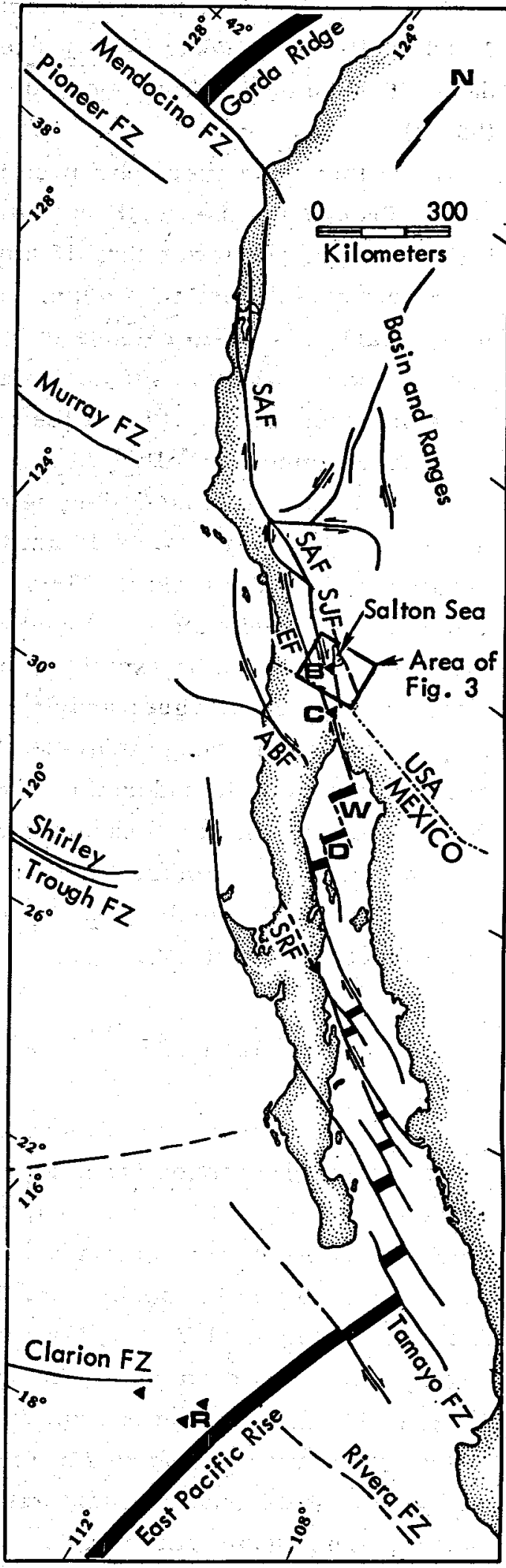

$\Delta=$ Holocene volcanoes; $B=$ Salton Buttes; C = Cerro Prieto; and $\mathrm{R}=\mathrm{Revillagigedo.} \mathrm{(Source:}$ Elders, et al.. 1972.) 
southeast of Brawley, produced more than 1,000 small earthquakes in only a few days (36 were of Richter magnitude greater than 3).

All of the hypocenters observed in the Salton Trough and the Northern Gulf of California are shallower than $15 \mathrm{~km}$ and most originate at less than $6 \mathrm{~km}$. Therefore, nearly all strain release is in the upper $10 \mathrm{~km}$. Work on surface seismicwave dispersion suggests that the crust beneath the Imperial Valley thins to about $20 \mathrm{~km}$ and that the crust under the northern half of the Gulf may be only $10 \mathrm{~km}$ thick (Thatcher, in Elders and Biehler, 1975). Certainly; a large part of the regional gravity anomaly can be explained in this way. A complete Bouguer gravity-anomaly map of the Salton Trough indicates that, although the basin is underlain by low density sediments, it is characterized by a broad gravity maximum, another indication of thin crust (Biehler, et al., 1964 and Elders, et al., 1972).

\section{SEDIMENTARY HISTORY}

The present apex of the Colorado River delta forms a low divide $(11 \mathrm{~m}$ above sea level at its lowest point) between the Imperial Valley to the north and the Mexicali Valley to the south (Fig. 3). Most of the Imperial Valley lies below sea level. At its northern end is the Salton Sea, which covers about $930 \mathrm{~km}^{2}$ and has a surface elevation of about $71 \mathrm{~m}$ below sea level. Water entering this basin can only escape by evaporation. The Colorado River enters the Salton Trough from the east at Yuma $43 \mathrm{~m}$ above sea level. The delta slopes northward (at $0.8 \mathrm{~m} / \mathrm{km}$ ) into the Salton Basin and southward (at $\sim 0.35 \mathrm{~m} / \mathrm{km}$ ) to the Gulf of California (Thompson, 1968). During 1905 to 1907. the Colorado flooded over the delta crest into the Salton Basin, forming the Salton Sea (Sykes, 1937). Although now the natural discharge of the River is into the Gulf of California, inflow of Colorado River water via irrigation canals permits the Salton Sea to persist.

These observations are the key to understanding the history of sedimentation in the basin. The Salton Trough is an actively growing rift valley, in which sedimentation has almost kept pace with tectonism. Formation of the delta perpendicular to the length of the Gulf of California rift has isolated the Salton Basin from the Gulf, forming a closed sedimentary basin $200 \mathrm{~km}$ long and up to $130 \mathrm{~km}$ wide. Since its formation, the Salton Basin has undergone cycles of filling with freshwater lakes and desiccation as the Colorado River changed course, alternately flowing north or south. Sediments from the walls of the Basin form marginal alluvial fans, but the Colorado River has dominated its sedimentary history. The deltaic deposits consist of interbedded sand, silts, clays, and pebble conglomerates (Van De Kamp, 1973). These rocks are interpersed with lake sediments and reworked eolian deposits. The percentage of sand bodies in the delta sediments decreases away from the delta apex towards the northwest (Randall, 1971). However, rather little is known of the nature and age of the sedimentary rocks in the central part of the Basin. The deepest well yet drilled in the Imperial Valley (Standard Oil of California, Wilson \#1) penetrated $4 \mathrm{~km}$ of Pleistocene fluvatile and lacustrine sediments (Merriam and Bandy, 1965; Muffler and Doe, 1968). 
The stratigraphy of the Neogene rocks cropping out in structurally complex zones on both sides of the Imperial Valley have been summarized by Dibblee (1954). Included in these formations are a few marine units, the oldest of which may be as old as Miocene. Maximum marine submergence occurred during the Pliocene, and intermittent shallow marine environments persisted in the western part of the Imperial Valley until middle Pleistocene (Woodward, 1974), Such marine rocks have not been reported from any of the numerous drill holes in the main part of the valley.

\section{THERMAL ANOMALIES}

The Salton Trough is characterized by numerous areas of very high temperature gradients at shallow depth. In addition to the Cerro Prieto geothermal field (C in Fig. 4), 8 or 10 anomalously hot zones are known in the Imperial Valley (Fig. 5). The high thermal gradients are thought to be related to circulation of convecting hot groundwater in the thick sedimentary fill (Dutcher, et al., 1972). These thermal anomalies coincide with low-amplitude, positive, residual-gravity anomalies with closures of 2 to 20 mgals (Biehler, in

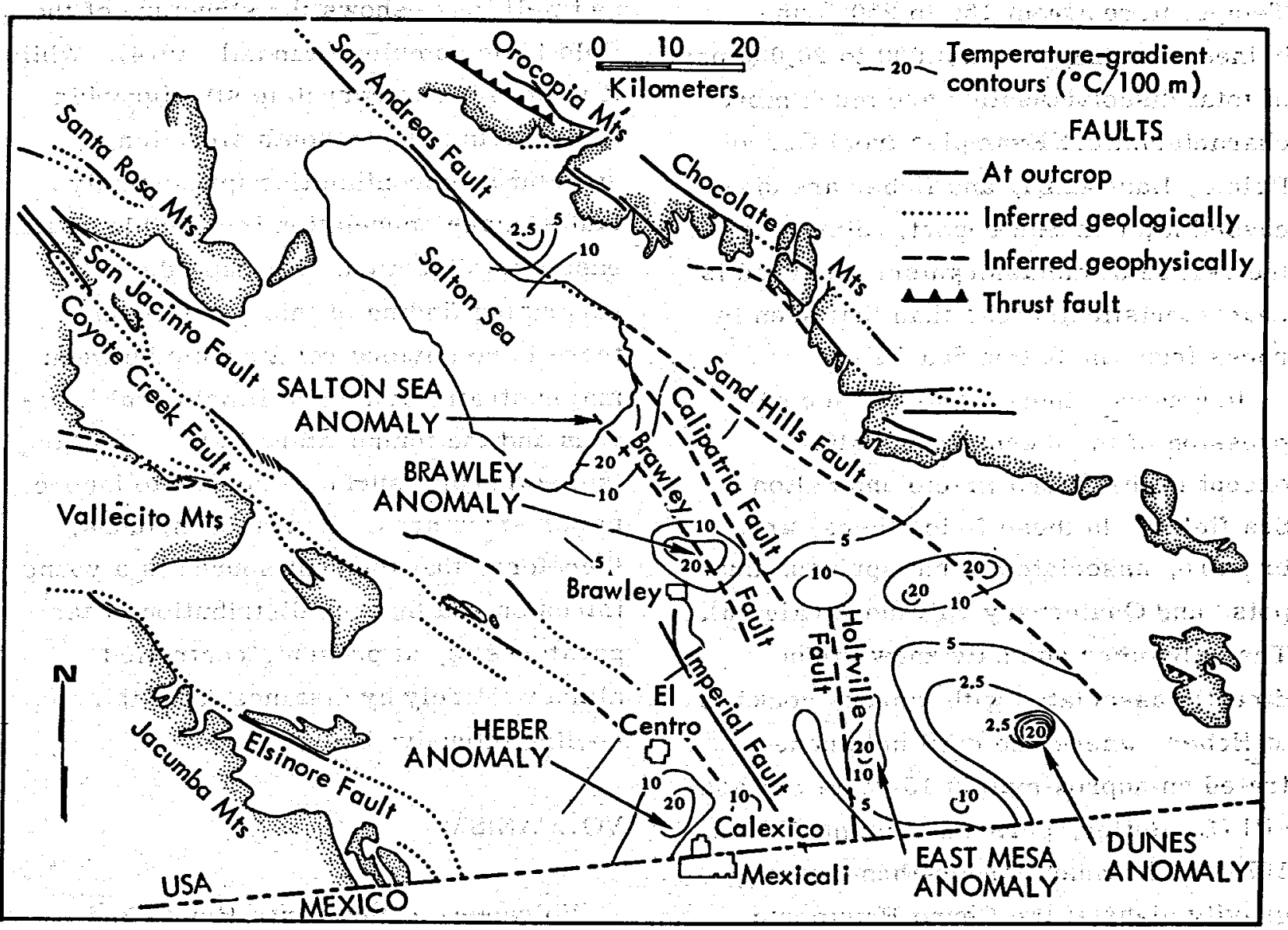

Fig. 5. Faults and geothermal areas in the Imperial Valley. Contours indicate nearsurface temperature gradients $\left({ }^{\circ} \mathrm{C} / 100 \mathrm{~m}\right)$ measured in more than 100 shallow : boreholes, using data up to 1972. Dot pattern indicates basement rock outcrops. (Source: Elders, et al., 1972.) 
Rex, et al., 1971). The excess mass in the subsurface has been attributed, at least in part, to thermal metamorphism of the sedimentary rocks by the hot brines. For example, intense metamorphism of the sedimentary fill occurs in the Salton Sea geothermal field. Active formation of greenschist facies rocks is occurring at depths of 1 to $2.5 \mathrm{~km}$ below the surface, where the temperature ranges from 300 to $350^{\circ} \mathrm{C}$ (Muffler and White, 1969). Brines recovered from these depths contain up to $25 \mathrm{wt} \%$ of total dissolved solids (Helgeson, 1968).

Such high temperatures and highly saline brines have not been found in the other thermal anomalies drilled to date. Temperatures from 150 to $250^{\circ} \mathrm{C}$ and brines containing from 3,000 to $20,000 \mathrm{ppm}$ of total dissolved solids are much more characteristic. Examples from Cerro Prieto, East Mesa, and Heber are discussed later in this report. Similarly, the degree of metamorphism observed is characteristically less than that seen in rocks from the Salton Sea field.

In general, there is no surface expression of the thermal anomalies, except in the Cerro Prieto and Salton Sea fields. In these fields there are, or were, associated warm springs, mudpots, and Quaternary volvanoes (Fig. 3). The only other anomaly known to be directly associated with igneous rocks is at Heber, where one drill hole penetrated an approximately $15-\mathrm{m}$-thick basalt sill (D. Butler, personal communication, 1974). The much larger-than-average gravity highs at the Cerro Prieto and Salton Sea fields are presumed to be associated with igneous intrusions at depth.
Surface expression of the thermal anomalies is retarded by impermeable caprocks. For example, the Salton Sea geothermal field has an impermeable caprock of lacustrine clays up to $450 \mathrm{~m}$ thick (Helgeson, 1968; Randall, 1974). The Dunes hydrothermal system, on the other hand, has an impermeable caprock developed by self-sealing. In the upper $300 \mathrm{~m}$ of a $612-\mathrm{m}$ deep borehole in this anomaly, there are seven intervals of intense sandstone-to-quartzite cementation, with densities as high as $2.55 \mathrm{~g} / \mathrm{cm}^{3}$ and porosities as low as $3 \%$ (E1ders and Bird, 1974; Bird, 1975).

A recently completed study of the Salton Sea anomaly, based on subsurface samples and well logs, shows the structure of the field to be complex (Randall, 1974). While it is possible to correlate stratigraphic horizons in a north-south direction, structural discontinuities (presumably faults) make correlation impossible in an east-west direction. Perhaps the most surprising finding of this study is that there is no obvious relationship between major stratigraphic and lithological horizons and the temperature field. Similarly, the isothermal surfaces appear to ignore major structures. Randall concludes, therefore, that the heat source is a young intrusion and that the distribution of temperatures is, at present, controlled almost entirely by distance from this cooling intrusive body.

\section{VOLCANISM}

Volcanoes at the Cerro Prieto and Salton Sea fields are apparently part of the suite of volcanic activity associated with the East Pacific Rise and the Gulf of 
California. The Barcena volcano in the Revillagigedo Islands on the East Pacific Rise ( $R$ in Fig. 4) erupted in 1952. Basalt dredged from the deep basins in the Gulf is olivine tholeiite similar to that found on the East Pacific Rise and other ocean spreading centers (Hawkins, in Elders and Biehler, 1975). No detailed studies of the Cerro Prieto volcano have been published; however, it is a lithoidal rhyodacite cone, which appears to be the product of a single eruptive cycle. The marked lack of erosion of the cone attests to the relatively youthful age of this eruption. It is on this basis that I have indicated it in Fig. 3 as being Quaternary in age.

At the south end of the Salton Sea are five small extrusive rhyolite domes arranged along a northeast trend. These domes, collectively known as the Salton Buttes, were extruded onto Quaternary alluvium. A single $\mathrm{K}-\mathrm{Ar}$ age determination on the westernmost dome, Obsidian Butte, gave an age of approximately 16,000 years (Muffler and White, 1969). Two of the domes, those at Red Hill, are linked by subaqueous pyroclastic deposits; the others are single extrusions with or without marginal lava flows. All of the domes consist of low-calcium, alkali rhyolite with only 1 or $2 \%$ crystals. Similar rocks recovered from geothermal wells had been altered extensively by water-rock reactions. The fresh rhyolites are identical in composition to soda rhyolites erupted on the islands of the East Pacific Rise (Robinson, Elders, and Muffler, 1975). Basaltic rocks occur as xenoliths in the domes and as subsurface dikes, sills, or flows. Except where hydrothermally altered by brines, these rocks are also identical to low-potassium tholeiitic basalts erupted on the East Pacific Rise and on islands in the Gulf of California (Robinson, Elders and Muffler, 1975). These observations support the hypothesis that the conditions that control magma genesis under the Salton Trough and the Gulf of California are similar to those operating beneath oceanic spreading centers.

Numerous partly melted granitic xenoliths in these rhyolite domes show various degrees of either cotectic melting along quartz-feldspar boundaries or disequilibrium incongruent melting of hydrous ferromagnesian minerals. These granite inclusions contain notably higher $\mathrm{SiO}_{2}$, $\mathrm{CaO}$, and $\mathrm{Na}_{2} \mathrm{O}$ and lower total iron than the enclosing rhyolite. The compositions and textures of these rocks suggest that they are fragments of the basement rather than being cogenetic with the rhyolites. This bimodal basalt-rhyolite assemblage in the Salton Sea geothermal field is believed to have formed in two stages by partial fusion of mantle peridotite, forming successive rhyolitic and basaltic melts. After formation, the rhyolite . magma was partly contaminated by continental crust material.

A compound, positive, magnetic anomaly only in part due to the exposed rhyolites is associated with the Salton Sea geothermal field. A long magnetic high, 5 to $8 \mathrm{~km}$ wide, is centered on the southern half of the lake and extends $28 \mathrm{~km}$ in a northwesterly direction. Griscom and Muffler (1971) interpret this high as being due to intrusive rocks at depths greater than 2 to $2.5 \mathrm{~km}$. These rocks may take the form of a stock-sized pluton or a concentrated dike swarm. Also, 
associated with the magnetic and heat-flow anomaly is a residual-gravity anomaly of approximately 22 mgals. The amplitude of the gravity anomaly suggests a center of gravity for the excess mass at about $6 \mathrm{~km}$ depth (Biehler, personal communication, 1974): Therefore, there are several lines of evidence indicating that the heat source for this anomaly is an igneous intrusion. A combined geological, geophysical; and geochemical investigation is underway at the University of California at Riverside to investigate the Salton: Sea geothermal field much more thoroughly.

\section{TECTONICS}

The crust in the Salton Trough is being actively deformed. Since triangulations began in 1931, there appears to have been about $2 \mathrm{~m}$ of differential, right-lateral movement in the southern part of the Imperial Valley: Similarly, there have been downward level changes of tens of centimeters during this period. The most notable deformations of the survey net are associated with the May 1940 earthquake on the Imperial Fault (7.1 magnitude on Richter scale). Clearly, the Imperial Valley as a whole is undergoing rightlateral horizontal motion and the center is subsiding relative to the walls by steady creep punctuated by earthquake activity (E) Elders, et al., 1972).

Viewed in context of regional tectonics, these modern earth strains provide a good model for the origin and history of the Trough. Overall, the region is characterized by a tectonic environment domi-a nated by strike-slip, or transform, faulting. However, at points where the transform faults are en echelon, tension gaps and compression zones are formed. The tension gaps, termed "rhombochasms" by Carey (1958) or "pull-apart basins" by Crowell (1974) predominate. These are sites of high heat flow and low topography where localized crustal spreading can occur. It is in these areas that new material can be introduced by leakage of magmas from the mantle as the crust thins (Elders, et al., 1972). Garfunkel (in Rex, et al., 1972) suggests that depressed areas on either side of the apex of the Colorado River delta may be subtle expressions of such tectonic subsidence that have not been obliterated by sedimentation. The en echelon arrangement of the western boundary of the Imperial Valley, with its numerous low embayments, also supports this idea. Figure 6 shows a possible arrangement of tension "pull-apart" basins, compression zones, and strike-slip faults. For example, young volcanic rocks crop out at Consag Rock in the Wagner Basin (W in Fig. 4), the northernmost of the closed basins in the gulf of California. Thatcher and Brune (1971) have described an earthquake swarm that occurred in this bas in in 1969 . Over 70 shocks, with magnitudes of between 4.0 and 5.5 (Richter scale), occurred during a 6-hr period. At the same time, there appeared to be a sympathetic coupling with earthquakes in the next basin to the south, the Delfin Basin (D in Fig. 4). These two basins appear to be related by a transform fault system. Lomnitz, et al., (1970) and Elders, et al., (1972) have suggested that this pattern of transform faults and "pull-apart" basins persists to the north. The location of Cerro Prieto between the San Jacinto 


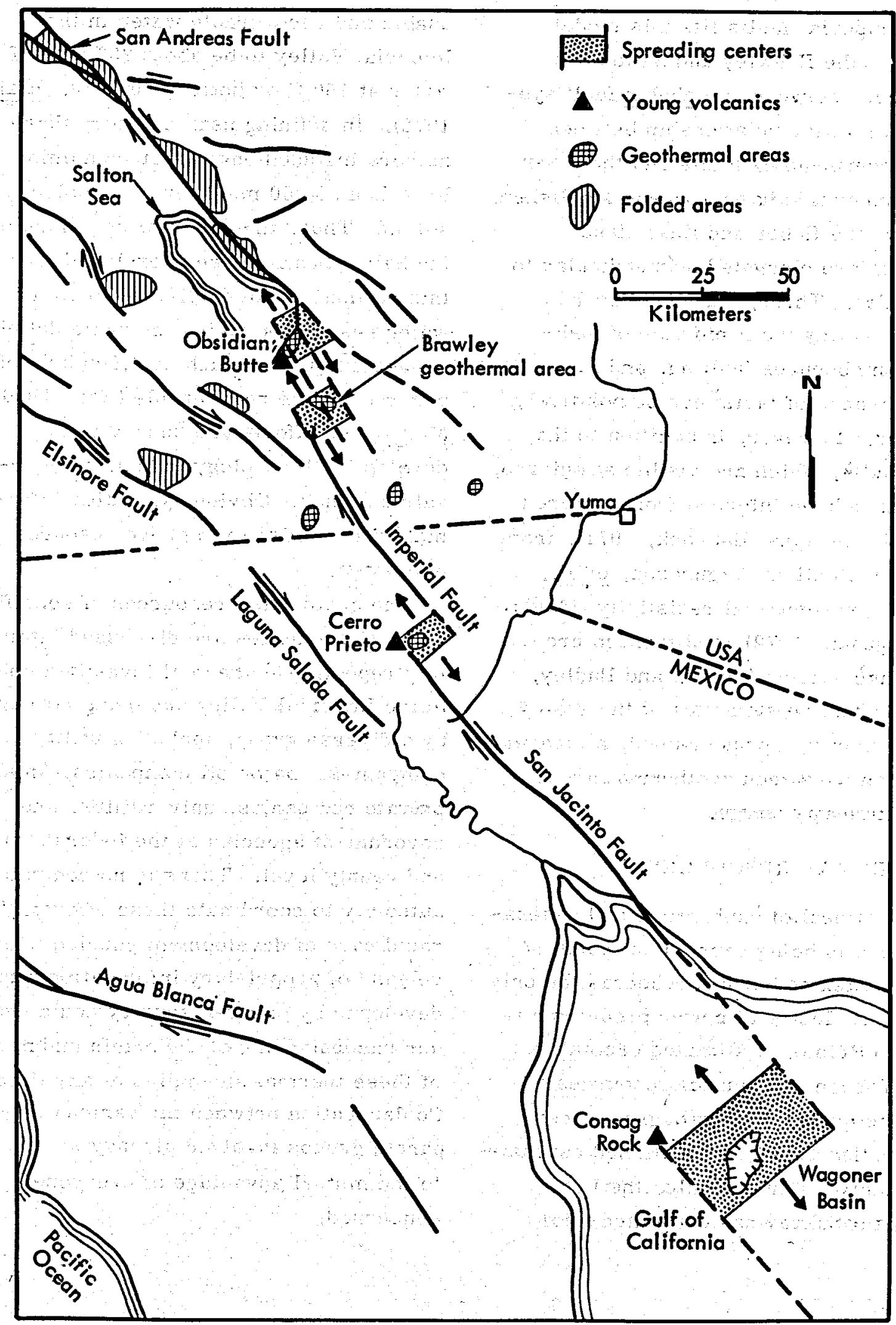

Fig. 6. Possible relationship between pull-apart basins and strike-slip faulting in the Saltion Trough. Postulated "spreading centers" or tensional zones, young volcanics, geothermal areas, and zones of intense folding and compression in Tertiary sediments are indicated. (Source: Elders, et al., 1972.) 
and the Imperial faults fits this model. Similarly, the Brawley and Salton Sea fields occur between en echelon fault systems. A similar relationship between major through-going faults and the other geothermal fields has not been established. However, the Heber and East Mesa anomalies are elongated perpendicular to local faults. Throughout much of the Imperial Valley the rapid rate of sedimentation obscures faulting, and few surface traces of faults can be positively identified. However, in addition to the major faults, which are visible at outcrop, others have been inferred from infrared aerial photographs (Babcock, 1971), from seismic reflections (Sigurdson, et al., 1971), from electrical resistivity (Meidav and Ferguson, 1972), and from microearthquake studies (Combs and Hadley, 1974). When the structure of the Valley is more thoroughly understood, a clearer relationship between geothermal areas and faults may emerge.

\section{GEOTHERMAL RESOURCES}

A great deal of exploration and assessment work is being carried out north of the U.S.-Mexico border, whereas the only significant electrical power production is at Cerro Prieto. Estimates of total Salton Trough geothermal resources cannot be made with any degree of certainty at this time, and published estimates vary widely. For example, the U.S. Geological Survey has estiamted total usable and recoverable water in the Imperial Valley to be about $250 \mathrm{~km}^{3}$ of water at $150^{\circ} \mathrm{C}$ or hotter (Dutcher, et al., 1972). In defining usable water, these authors included only water containing less than $35,000 \mathrm{mg} /$ liter of dissolved solids. Thus, the hypersaline brines of the Salton Sea field were excluded from this estimate. An earlier estimate of water resources, using the same definition, suggested that as much as $6,000 \mathrm{~km}^{3}$ of water might be recoverable (Rex, 1970). Moreover, efforts are underway to develop the technology to handle hypersaline brines. Obviously, better information is needed to improve resource estimates.

The geothermal resources of specific thermal anomalies are discussed later in this report. Geothermal investigations in the Imperial Valley are being conducted by a diverse group, including utility companies, major oil companies, small private companies, universities, and government agencies at the federal, state, and county level. There is no centralized authority to coordinate these efforts. The rapid pace of development coupled with the release of proprietary information already developed by private industry could change our understanding of the origin and nature of these thermal anomalies at any time. Coolaboration between the various disparate groups involved already is occurring to the mutual advantage of everyone concerned. 


\section{History: Salton Trough Geothermal Development*}

The existence of geothermal activity in the Salton Trough has been known for many years. Live steam fumaroles, mud volcanoes, and boiling mudpots (Figs. 7 and 8 ) were observed by the area's earliest inhabitants in the Salton Sea near the volcanic outcrop now known as Mullet Island. The first attempts at resource recovery began here and, in following years, spread to other areas of the Salton Trough: Brawley, East Mesa, Heber, and Cerro Prieto.

The first exploratory geothermal wells were drilled on Mullet Island in 1927 by the Pioneer Development Company (Fig. 9). Three wells were drilled into this volcanic dome, the deepest to a depth of $449 \mathrm{~m}$. Steam and hot water were found in all three wells, but pressure and water volume were not sufficient for commercial operation so the wells were abandoned. However, in drilling these wells, it was noted that a large volume of carbon dioxide gas was produced. This observation led to the discovery of the adjacent Imperial Carbon Dioxide Field, which, from 1933 to 1954 , supported some 55 producing wells. The carbon dioxide was recovered from shallow sands (150 to $200 \mathrm{~m}$ deep). containing hot water (as high as $66^{\circ} \mathrm{C}$ ). In conjunction with the field, two processing plants were built in the area to convert the carbon dixoide to dry ice.

The first exploratory well to produce substantial amounts of steam and hot water was the Kent Imperial Corporation's
Sinclair \#1, located near Niland in the Imperial Valley (Fig. 10). Originally an oil prospect, this well was drilled in 1957-58 to a depth of $1440 \mathrm{~m}$. However, when tests of the most promising oil zone produced only hot water and steam, the site was prepared for steam production. In 1959 , a small pilot plant (including separators, condensers, and generators) was installed at the well. The plant operated intermittently for 4 months before being shut down when the well scaled up at the surface. The well has not produced since.

From 1961 to 1964 , a number of geothermal wells were drilled in the Salton Sea area. The first was the Joseph I. O'Neill, Jr., Sportsman \#1 about $6 \mathrm{~km}$ northeast of Sinclair \#1 (Fig. 9). This 1441-m-deep well proved to be a good steam producer. As a result, 10 additional wells were drilled in the immediate vicinity, 8 of which also became success ful steam producers. All of these wells produced steam from hot water reservoirs flowing a mixture of steam and highsalinity water at the wellhead. Brine analyses showed surprisingly high mineral contents, some of the brines having total dissolved-solids concentrations of more than 300,000 ppm. This high salinity, accompanied by some caustic properties, caused severe corrosion and scaling problems in the wells and support equipment. Recognizing the potential for mineral recovery from the brines, Imperial. Thermal Products, Inc. (a subsidiary of

\footnotetext{
*Thomas D. Palmer, Earth Sciences Division, Lawrence Livermore Laboratory, Livermore, CA.

Don P. Lande, California Division of Oil \& Gas, Long Beach, CA.
} 


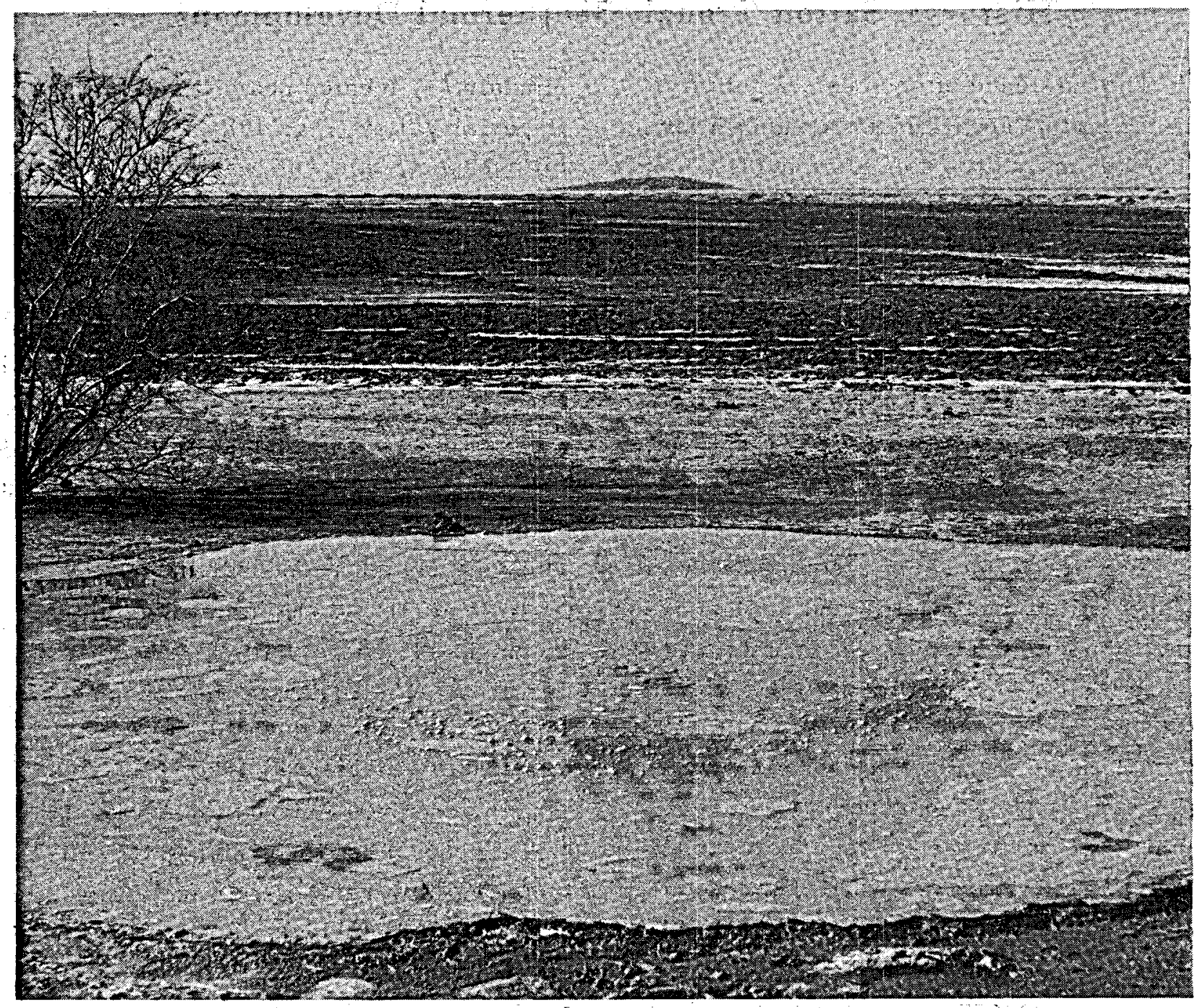

Fig. 7. Mud pots with carbon dioxide vents near, Mullet Island, Salton Sea area, California.

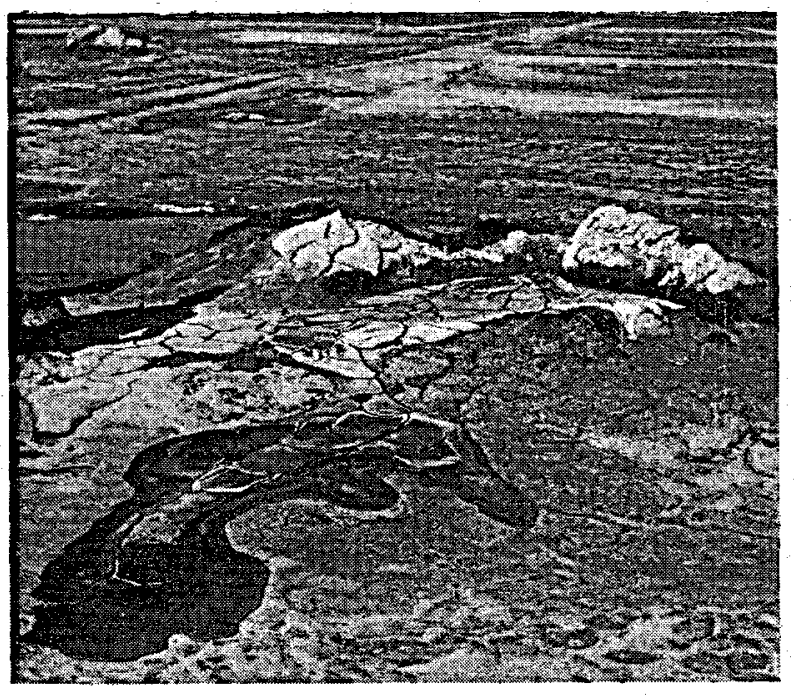

Fig. 8. Mud volcanoes near Mullet Island, Salton Sea area, California.
Morton International, Inc.) and the Earth Energy Co. (a subsidiary of Union-Pure Oil Co.) both located pilot powerproduction/mineral-recovery plants in the area. However, after several years of experimentation, these ventures were terminated as being uneconomical.

Also during this time period (1963), the Standard Oil Company of California drilled a 4,097-m-deep oil-exploration well in the vicinity of Brawley. When abnormally high temperatures were encountered, it prompted the Oil company to drill 17 shallow, temperature-test 


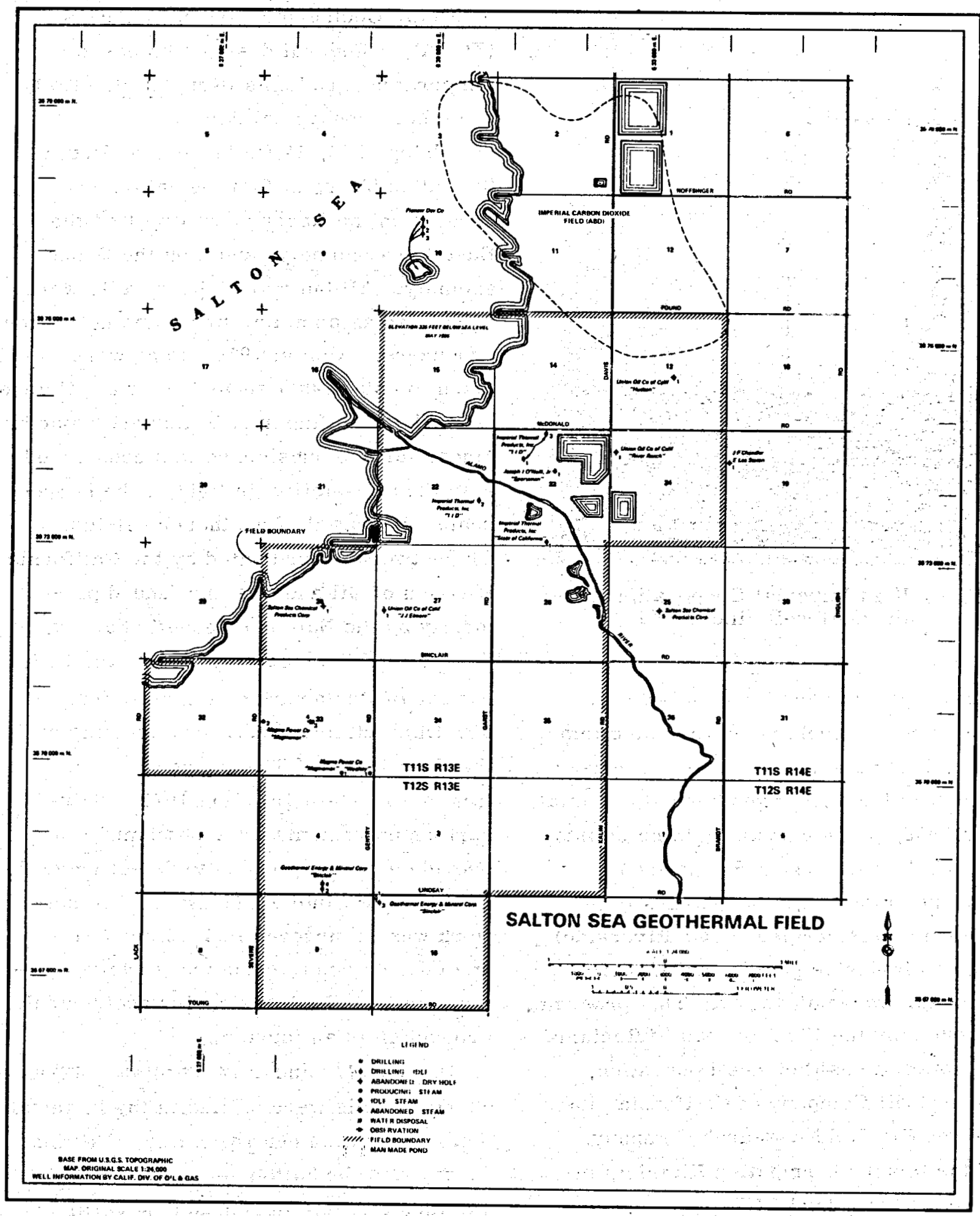

Fig. 9. Salton Sea Geothermal Field, geothermal well locations. 


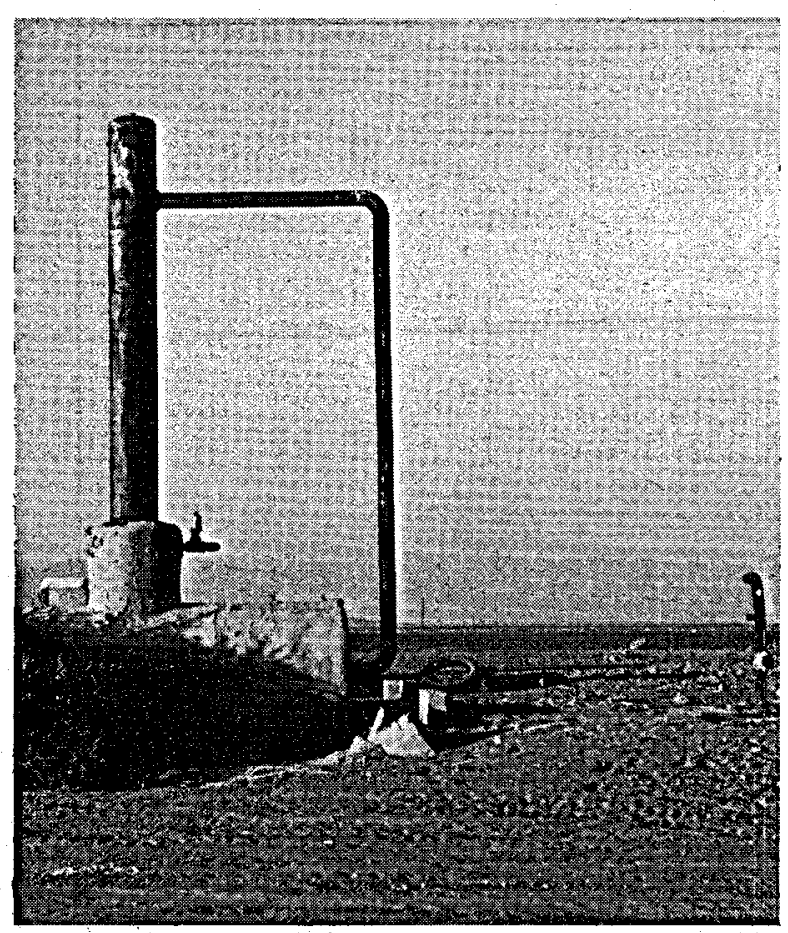

Fig. 10. Kent Imperial Corporation geothermal well Sinclair \#1.

holes in the southern Imperial Valley. When these test holes also indicated temperature anomolies, it greatly increased interest in the area's geothermal potential.

In 1968, primarily through the efforts of R.W. Rex (a former Standard Oil Company employee), the University of California at Riverside (U. C. Riverside) began an intensive geothermal investigation of the Imperial Valley. This program, supported by the U.S. Bureau of Reclamation, the National Science Foundation, Standard Oil Company of California, the Chevron Oil Field Research Company, and the Imperial Irrigation District, incorporated Standard Oil's previous work and included heat-flow measurements; resistivity, gravity, and seismic surveys; and more than 100 shallow-hole temperature tests. The study located several significant geothermal anomalies (Fig. 11), most of which have since been classified as Known Geothermal Resource Areas. (KGRA), a Federal designation based on temperature gradients (Rex, et al., 1971), and other geophysical data.

During 1972, 12 wells were drilled in the Salton Trough: 5 in the Salton Sea area, 3 on the Heber anomaly, 1 on the East Mesa anomaly, and 1 on the Dunes anomaly. All but two of these wells were completed as potential steam and hot-water producers. Also in 1972, steps were taken to establish a subsidence surveillance network in the Imperial Valley and adjacent lands; surface subsidence was considered a distinct possibility in light of the largescale withdrawal of geothermal fluids. The network, coordinated by the California Division of Oil and Gas and funded primarily by the National Geodetic Survey, the National Science Foundation, the U.S. Bureau of Reclamation, Imperial Irrigation District, the County of Imperial, and the U.S. Dept. of Transportation, was first surveyed in 1971 and 1972. Natural surface movements were determined to provide a basis by which to detect movements due to fluid withdrawal. The network was resurveyed in 1973 and 1974, and is to be resurveyed every two years more frequently, if extensive geothermal production is anticipated.

During 1973 and 1974 , a total of 12 geothermal wells were drilled in the Imperial Valley: 4 in the central valley, 4 at East Mesa, 1 in the Salton Sea area, and 3 in the Heber area." In addition, several ongoing experimental programs were initiated to test and evaluate methods, materials, and equipment for the handling and use of geothermal fluids. Three of these projects are being conducted in the Salton Sea area, one by the San Diego 


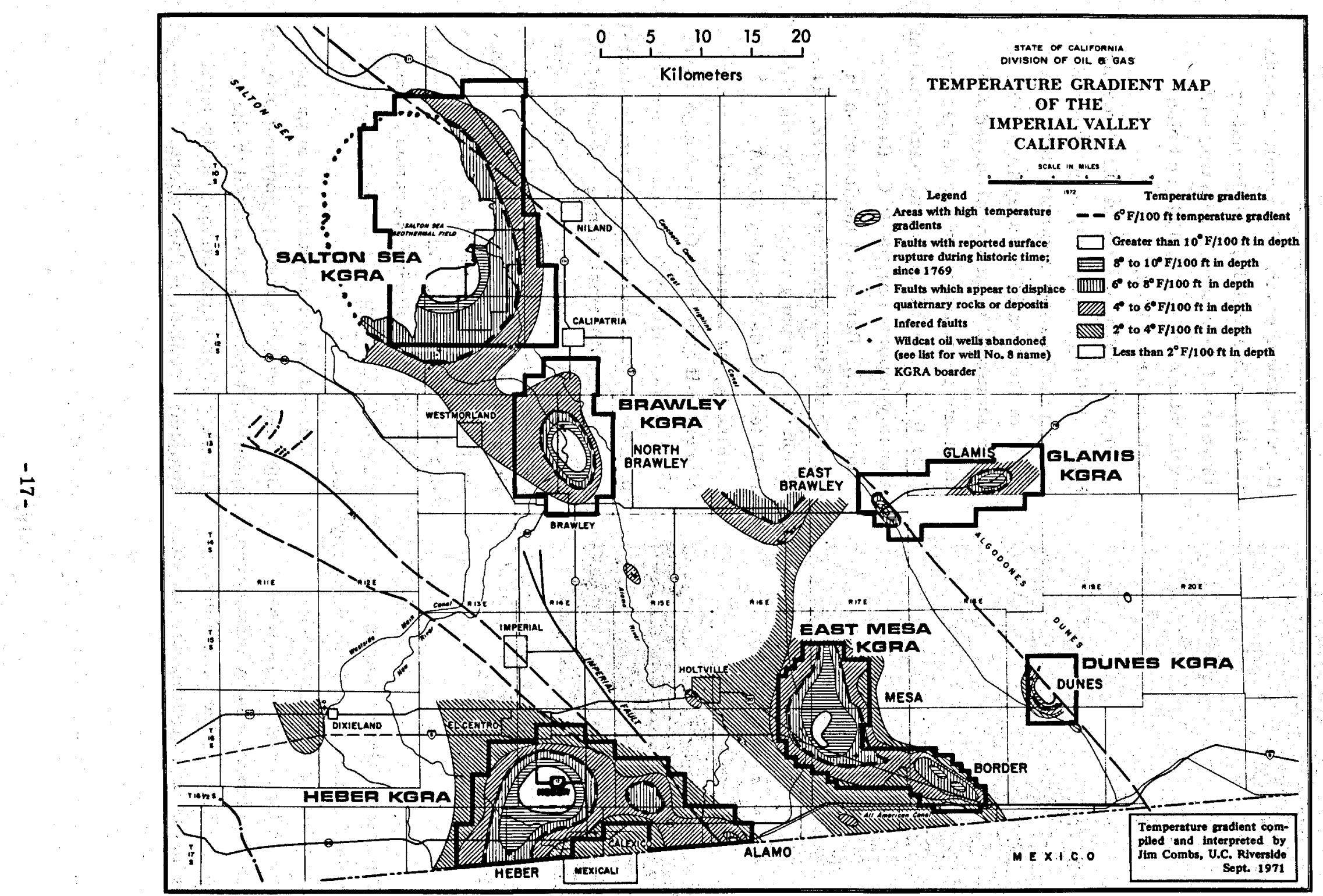

Fig. 11. Temperature gradient map of the Imperial Valley, California, showing KGRAs. 


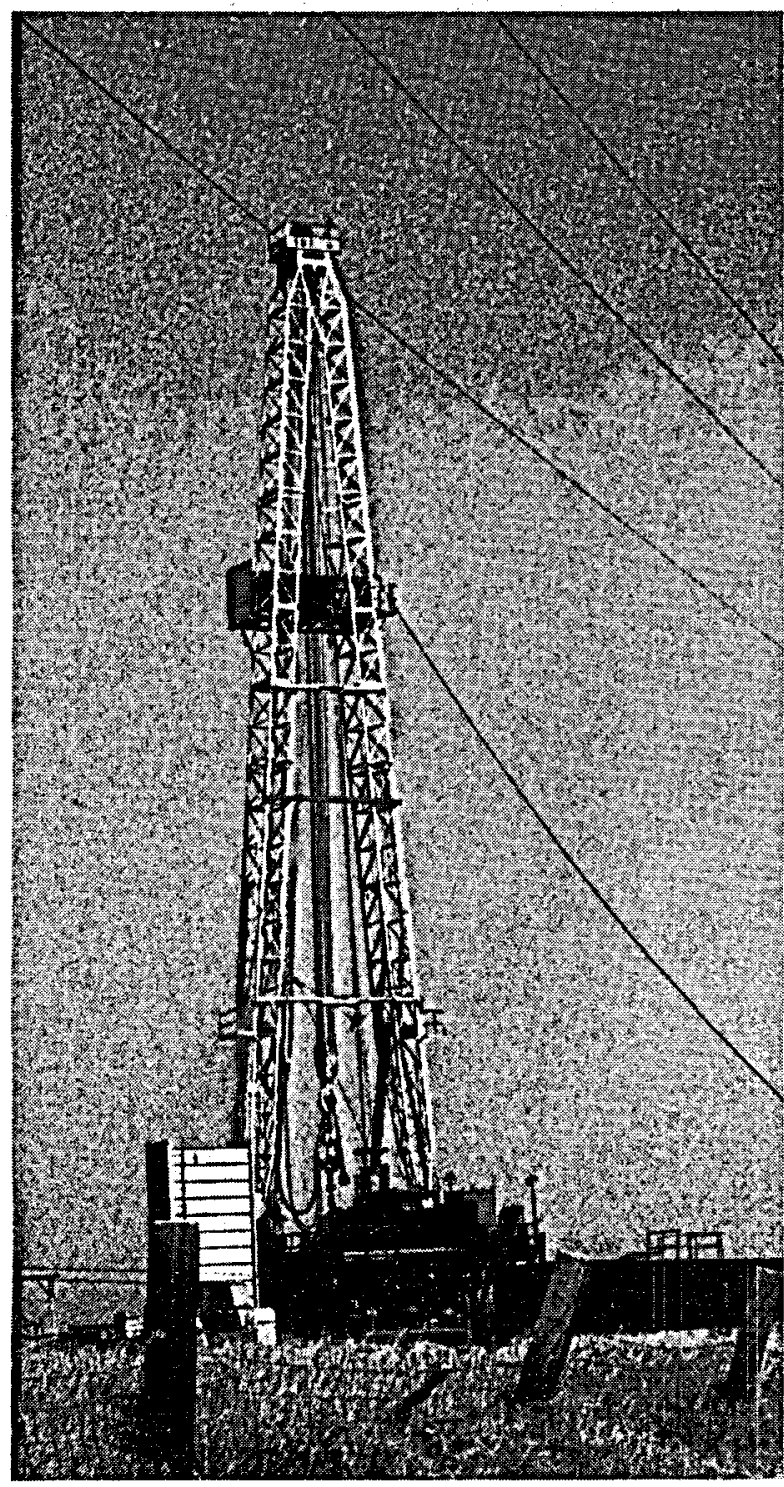

Fig. 12. Union Oil Company geothermal well Veysey \# 1, $4 \mathrm{~km}$ north of Brawley, California.

Gas and Electric (SDG\&E) Company, another by the Phillips Petroleum Company, and a third by the Lawrence Livermore Laboratory. A test program is also underway in the Heber area by the Chevron Oil Company. Finally, the U.S. Bureau of Reclamation is investigating the use of geothermal brines in two experimental desalination plants at East Mesa.

In the Mexicali Valley, the Mexican Government is operating a 75-MW geothermal power plant. Electricity generation began in April 1973, culminating 13 years of development starting with exploratory drilling in 1961 and plant construction in 1968.

In early 1975, the Union Oil Company began drilling Veysey \#1, a geothermal well on the Brawley anomaly about $4 \mathrm{~km}$ north of the town of Brawley (Fig. 12). Four additional wells are proposed for the same general area. These sites are near the center of the geothermal-gradient anomaly reported by the U.C. Riverside and the U.S. Bureau of Reclamation in their joint study published in 1972. These Union Oil Company wells will be the first field tests of the Brawley KGRA.

Finally, as mentioned earlier, the Morton Salt and Union Oil Companys have tried unsuccessfully to develop economic processes for large-scale mineral extraction from geothermal brines. Nonetheless, mineral-recovery projects continue. For the past several years, the Geothermal Energy and Mineral Corporation has been extracting calcium chloride from the brine of Sinclair well \#4. And a similar, smallscale calcium chloride operation is underway at the Morton Salt Company's IID \# 1 well.

More-detailed descriptions of the geothermal research and development projects mentioned here are presented in the "Industrial and Institutional Geothermal Projects" section of this report. 


\section{Industrial and Institutional Geothermal Projects}

IMPERIAL VALLEY *

The U.C. Riverside has been instrumental in developing the geothermal resources of the Imperial Valley. In 1968, a group of faculty and students, headed by R. W. Rex, began a series of geothermal study projects at the area that continue today. This program, supported by the National Science Foundation, the U.S. Bureau of Reclamation, the Academic Senate of U.C. Riverside, the Standard Oil Company of California, the Chevron Oil Field Research Company, and the Imperial Irrigation District, includes geological and geochemical studies, geothermal-gradient and heat-flow measurements, and resistivity, gravity, and marine seismic surveys. Since its inception, this field research program has identified five geothermal anomalies and a fault system in the area. Moreover, four of these anomalies were included in the U.S. Geological Survey's 1971 list of KGRA's (Fig. 8). During 1972, the California Department of Water Resources, in a joint effort with U.C. Riverside and the U.S. Bureau of Reclamation, drilled a $612-\mathrm{m}$ well on the Dunes anomaly. The Bureau of Reclamation also began a drilling program on the larger East Mesa anomaly the same year.

\author{
EAST MESA ${ }^{\dagger}$
}

At East Mesa (Fig. 13), the Bureau of Reclamation is exploring the feasibility of desalting geothermal brines and the practicability of concurrently generating electric power. Additional fresh water developed in the Imperial Valley can be used to augment flow in the Colorado River system, the most highly regulated and intensively utilized river system in the U.S. The recovery of marketable mineral products from blowdown brines is another possibility being investigated in this multipurpose research and development program.

A total of 60 test holes have been drilled into the East Mesa anomaly, and detailed temperature profiles have been measured in each. Based on these data, heat-flow values and contours have been computed, outlining the lateral extent of the Mesa anomaly (Fig. 14). Gravity, microearthquake, seismic noise, and resistivity methods have been used to further define the anomaly. To date, five test wells, each more than $1829 \mathrm{~m}$ deep, have been completed at the site. Bottom temperatures at these wells range from 150 to $200^{\circ} \mathrm{C}$. Mesa 6-1 and Mesa 6-2 are production wells. Mesa $5-1$ is being developed as an injection well, based on surface and subsurface geophysical data.

\footnotetext{
Don P. Lande, California Division of Oil \& Gas, Long Beach, CA.
}

\footnotetext{
$\Upsilon_{\text {U.S. Bureau of Reclamation, Boulder }}$ City, NV.
} 


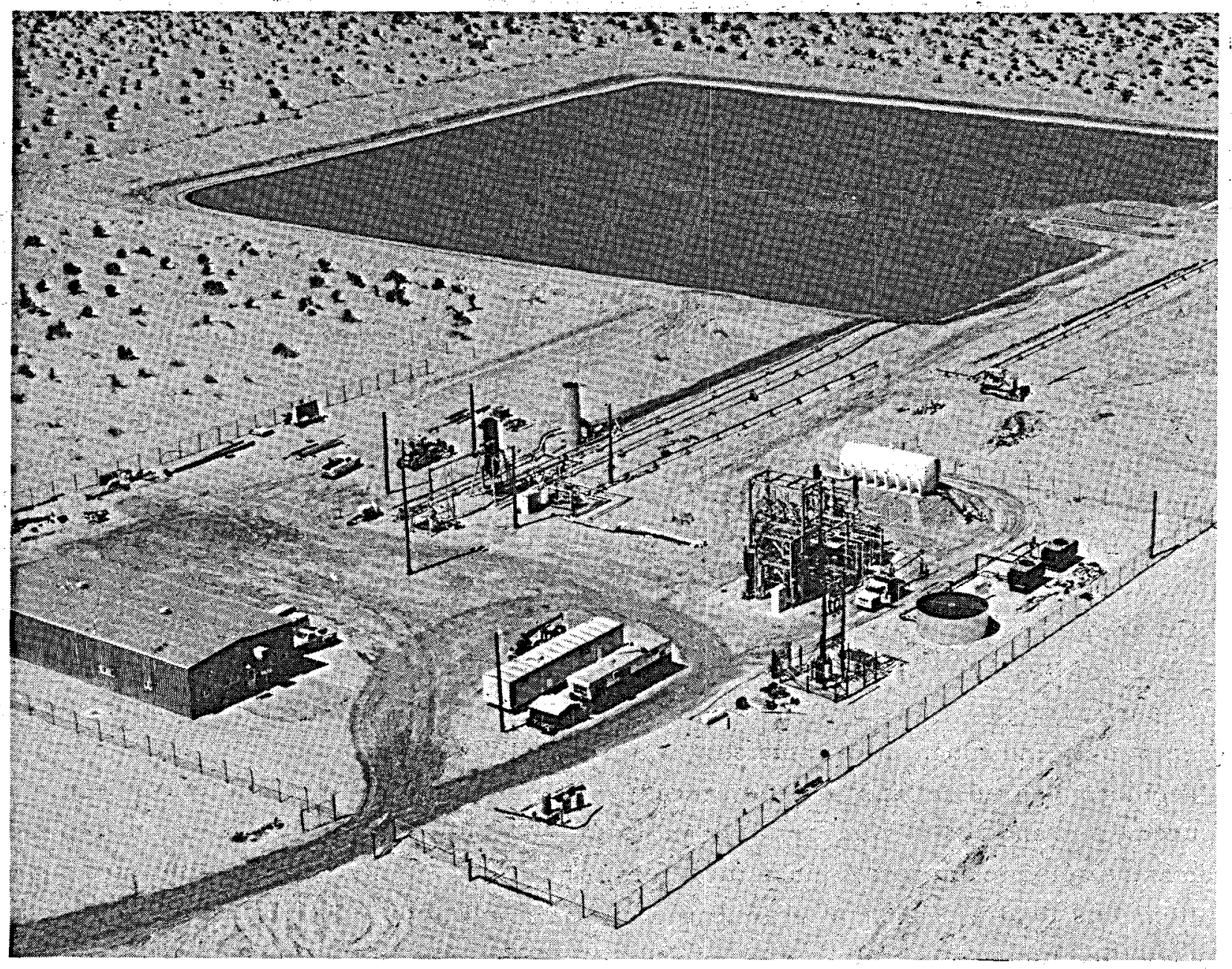

Fig. 13. Bureau of Reclamation East Mesa test site, Imperial Valley, California. Geothermal test facility and well Mesa 6-1 in foreground; brine holding pond in background. (Photo courtesy of U.S. Bureau of Reclamation.)

The other twowells, Mesa 31-1 and Mesa 8-1, are to be tested as production wells.

Two experimental desalination plants, a multistage flash-distillation unit (MSF) and a vertical-tube evaporator-distillation unit (VTE), are being used by the Bureau of Reclamation to test and evaluate procedures for desalting geothermal fluids. Each unit is designed to produce 75 to $190 \mathrm{kl}$ of distilled water per day, depending on operating conditions.

Distillation-type desalination methods are particularly attractive for geothermal brines because the fluids are naturally heated. To date, both plants have operated successfully and have produced tens of kiloliters of distilled water. The VTE has been run continuously in around-theclock operations, with no evidence of scaling or corrosion problems in the heat exchanger tubes. Operational data from these test desalination units will provide design criteria for larger, prototype units as well as information for the design of heat exchangers to be used in geothermal power-plant.

The East Mesa facility provides a setting where geothermal research and 


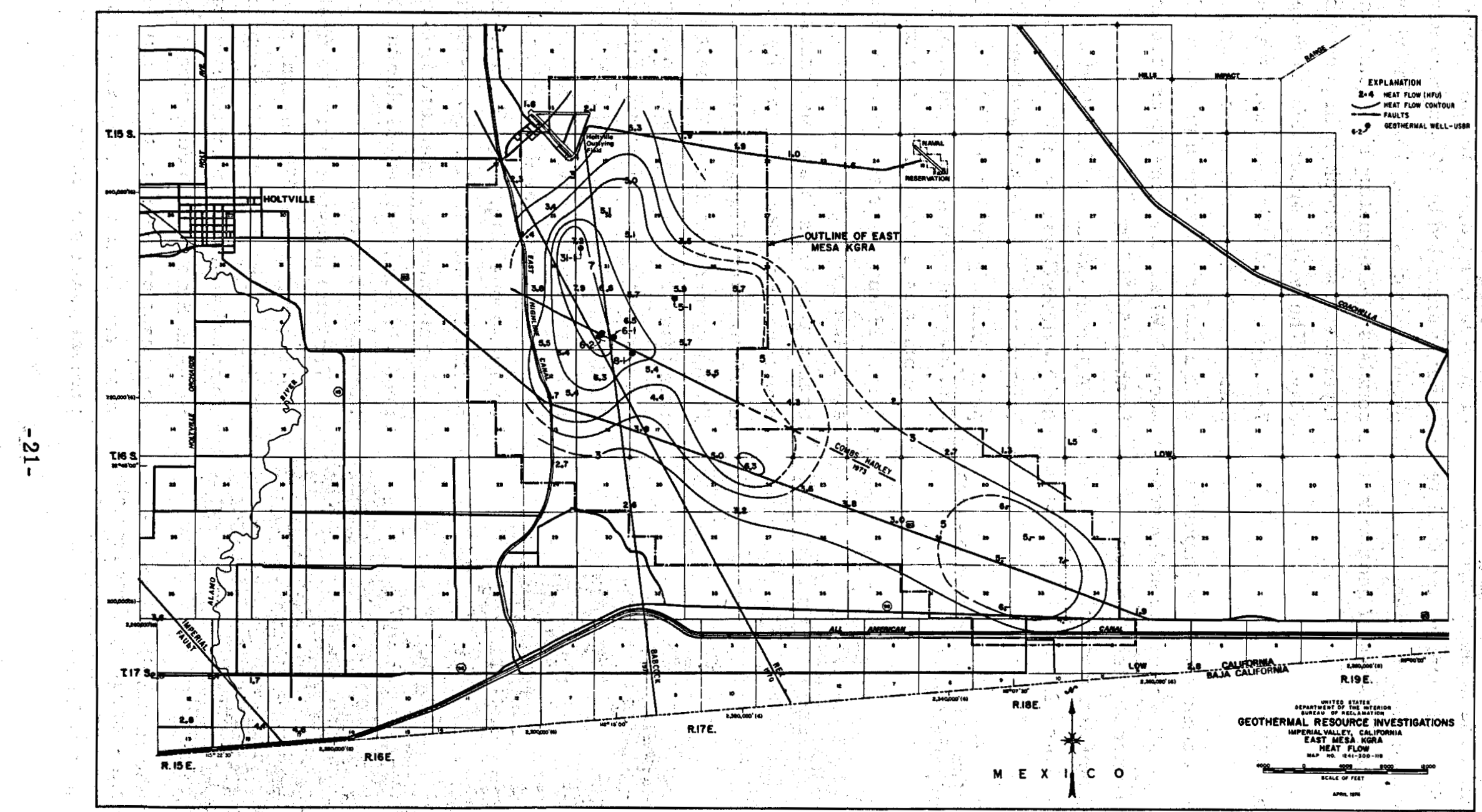
Fig. 14. Heat flow, U.S. Bureau of Reclamation Test Site, East Mesa, Imperial Valley, California. (Figure courtesy
of Bureau of Reclamation.) 
development can be performed under actual field conditions using producing geothermal wells. Therefore, the facility has been made available to scientists studying the characteristics of geothermal fluids.

\section{MEXICALI VALLEY *}

The southern extension of the Imperial Valley, the Mexicali Valley, is under geothermal development by the Mexican Government (Comision Federal De Electricidad). About $2.5 \mathrm{~km}^{2}$ of the Cerro

\footnotetext{
*Ing. Jorge Guiza L., Comision Federal de Electricidad, Mexico, D. F.
}

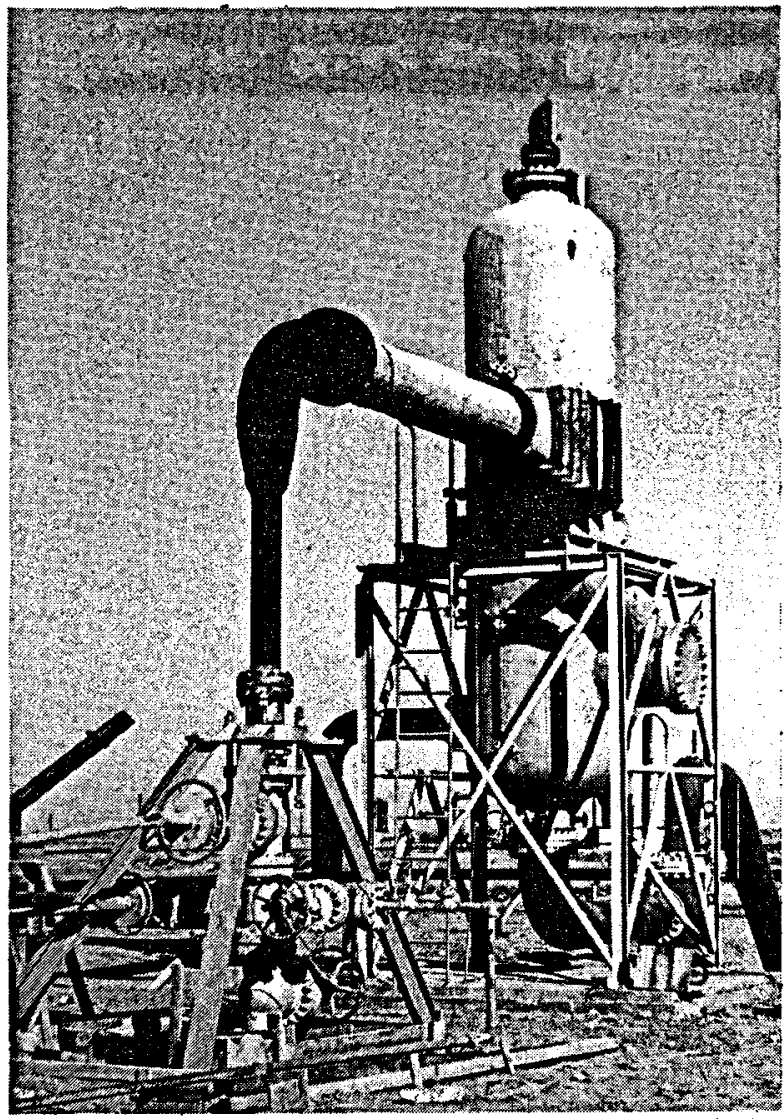

Fig. 15. Geothermal well and watersteam separator, Cerro Prieto power plant, Mexicali Valley, Baja, California.
Prieto geothermal field (about $32 \mathrm{~km}$ south of Mexicali, Baja, California) currently is being exploited by 30 steam/waterproducing wells (Fig. 15). The reservoir consists of alternating shale and sandstone layers with a cap rock of impermeable clay. The wells, about $1300 \mathrm{~m}$ deep, use 7-5/8-in. production casing. Maximum bottom-hole temperature is about $350^{\circ} \mathrm{C}$, with a maximum shut-in pressure of about $9 \mathrm{MPa}$. Average steam production is about $55,000 \mathrm{~kg} / \mathrm{hr}$.

After an extensive field-test program, the Mexican Government in 1968 started construction of a 75-MW geothermal power plant in the Mexicali Valley (Fig. 16). Commercial operation began in April 1973. The plant uses two Toshiba turbines (Figs. 17 and 18) in two $37,500-\mathrm{kW}$ turboalternator groups, having an admission pressure of $517 \mathrm{kPa}$ and an exhaust-steam pressure of $12 \mathrm{kPa}$. The facility operates on steam from 13 geothermal wells.

Steam condensers are of the barometric type (Fig. 19), with ejectors to extract incondensable gases (mainly carbon dioxide and hydrogen sulphide). As this is a hot-water reservoir, the separated saline water must be disposed of in evaporation ponds (Fig. 20). Salts from this discharge water are being considered as potential sources of marketable chemical products (e.g., potassium chloride and lithium carbonate).

The total investment for the first stage of this project was $\$ 20$ million, nearly $\$ 300$ per kilowatt of installed capacity. The total cost per generated kilowatt-hour is about $8 \mathrm{mils}$, including operation cost, amortization, depreciation, maintenance cost, and the cost of new wells to sustain present power generation. 


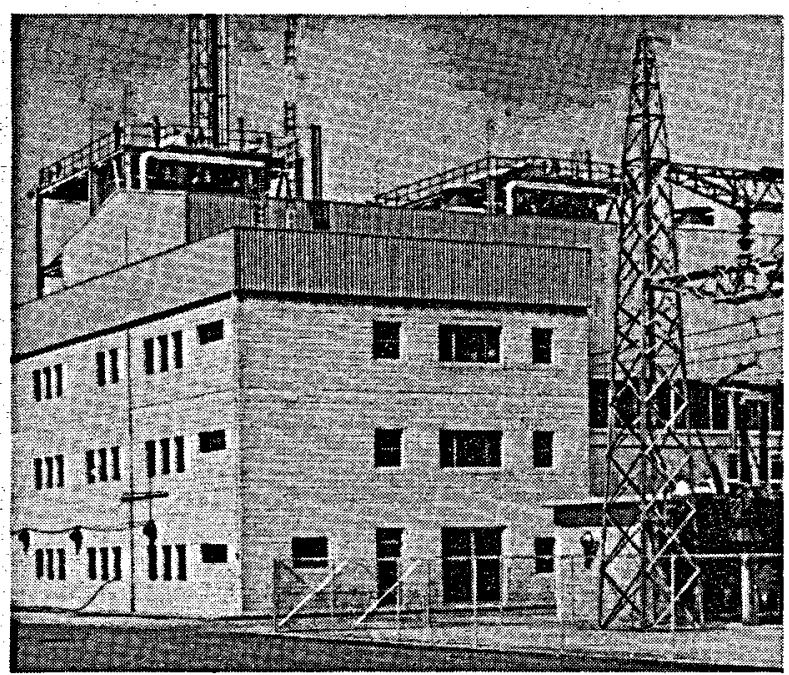

Fig. 16. Cerro Prieto geothermal power plant, Mexicali Valley, Baja, California.

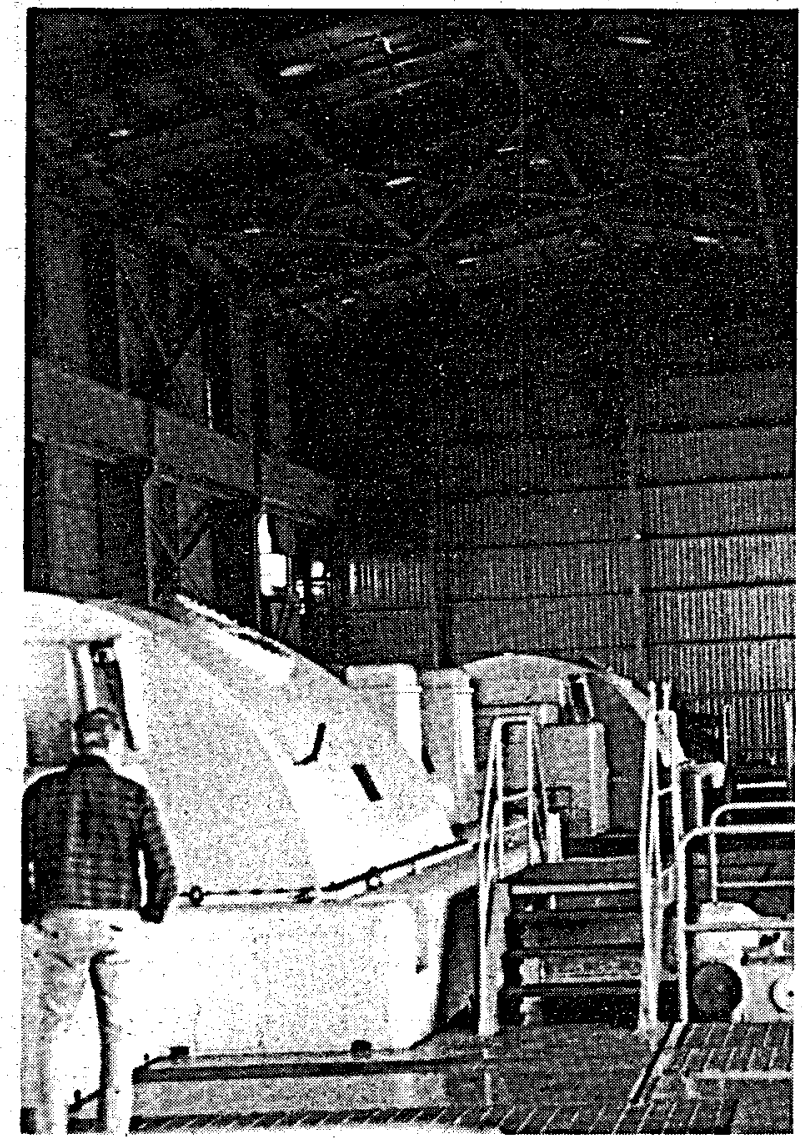

Fig. 17. Toshiba $37,500-\mathrm{kW}$ turboalternator groups, Cerro Prieto power plant, Mexicali Valley, Baja, California, Mexico.

\section{HEBER *}

Geothermal development in the Heber area has been due largely to the efforts of the Chevron Oil Company, Magma Power, and associated organizations. This area has been considered a potential heat anomaly since 1945, when Amerada drilled an oil and gas test well (Timkin \#1) just west of the Heber townsite. Well logs indicated a higher-than-normal heat gradient. In 1963, Chevron confirmed the Heber geothermal anomaly by drilling a shallow test hole and measuring the heat gradient. In 1971 , Chevron initiated a geophysical program to more fully evaluate the geothermal potential of the Heber area.

\footnotetext{
*David R. Butler, Chevron Oil Company, San Francisco, CA.
}

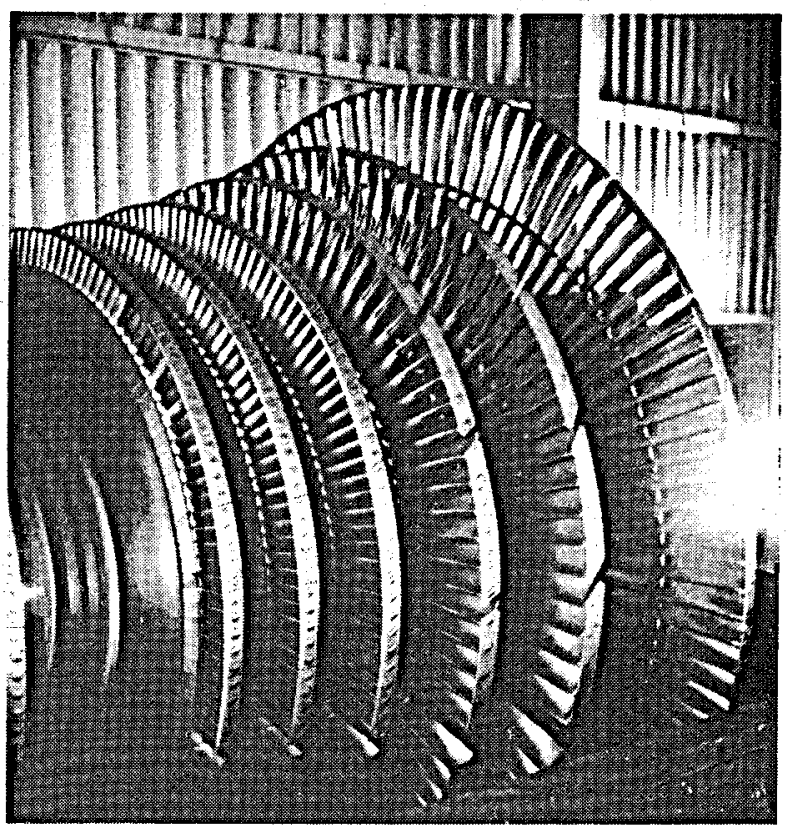

Fig. 18. Toshiba turbine rotor, Cerro Prieto power plant, Mexicali Valley, Baja, California. 


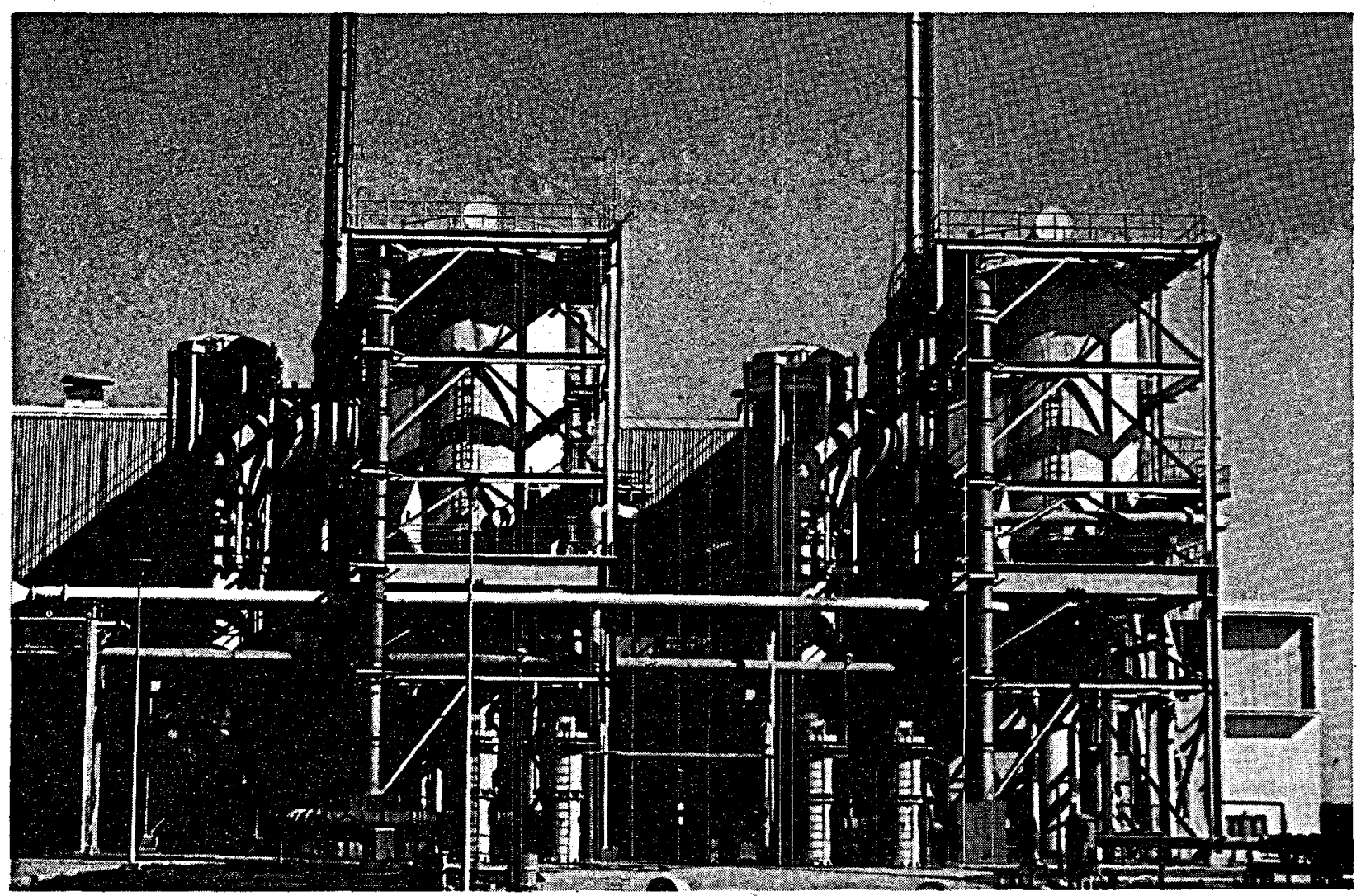

Fig. 19. Barometric steam condensers, Cerro Prieto power plant, Mexicali Valley, Baja California.

Early in 1972, Magma Energy, Inc., with the financial support of Chevron Oil Company, drilled the Hultz well \#1 to a depth of $1,569 \mathrm{~m}$. This and subsequent

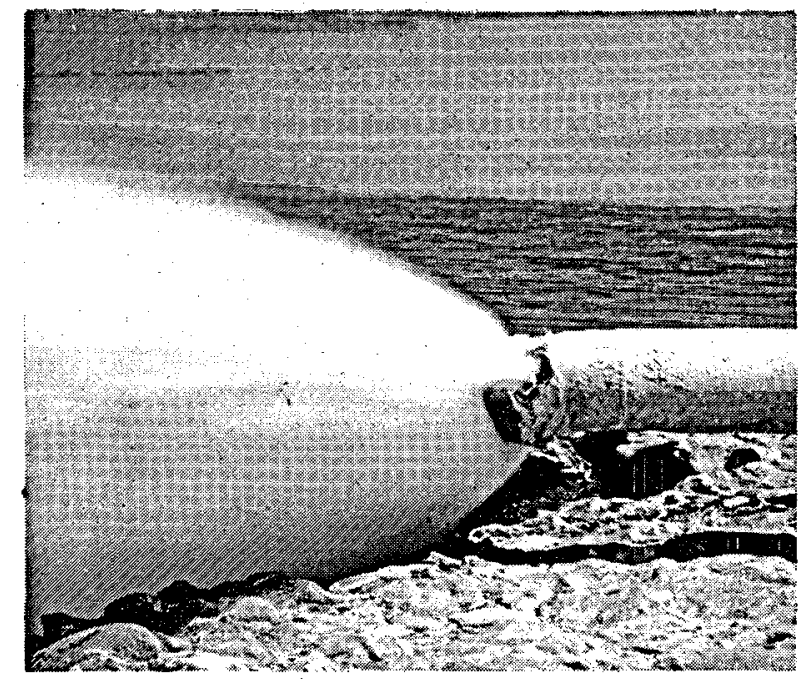

Fig. 20. Waste-water discharge to solar evaporation ponds, Cerro Prieto power plant, Mexicali Valley, Baja, California. wells, are shown in Fig. 21. Well conditions were encouraging and prompted Magma to drill a second, 1,524-m-deep well nearby. In the fall of 1972, Chevron drilled its first well, Nowlin Partnership \#1, to a depth of $1,533 \mathrm{~m}$.

In 1973, Chevron, New Albion Resources Company (a subsidiary of San Diego Gas and Electric Company) and Magma Energy agreed to a joint venture at Heber to test and evaluate the geothermal potential indicated in the earlier wells. Chevron was designated operator for the joint venture. The resulting test project began in late 1973 and was completed in mid-December 1974. The objective of this program was to determine production and injection capability of the Heber reservoir and to evaluate binary-cycle heat-exchange technology. Chevron's Nowlin Partnership \# 1 


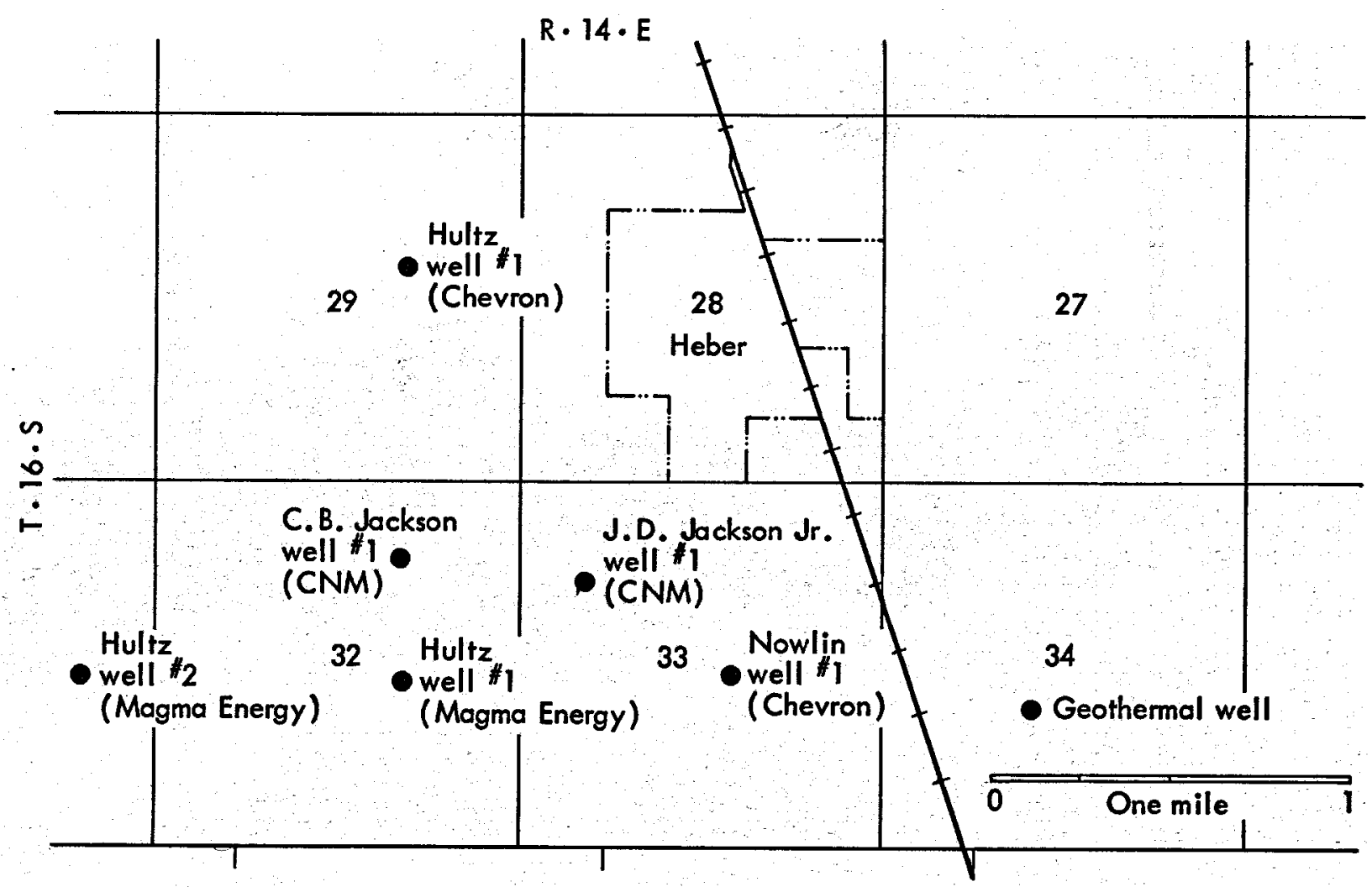

Fig. 21. Geothermal wells in the Heber area, Imperial Valley, California.

and Magma's Hultz well \#1 were produced, and reservoir fluids were injected into Magma's Hultz well \#2.

During the summer and fall of 1974 , Chevron drilled two additional wells for the joint venture and one of its own. Test data from these wells will be evaluated with that from other wells to determine if reservoir conditions warrant full-scale commercial development.

Because the Heber geothermal anomaly is in the moderate temperature range, the fluid must be pumped to enable a sufficiently high temperature to be maintained at the surface. The method anticipated to be applicable at Heber is a binary process using heat exchangers (Fig. 22).

Recently, San Diego Gas and Electric has installed a heat-exchanger test module at the Chevron site (Fig. 23) and is collecting information on heat-exchanger

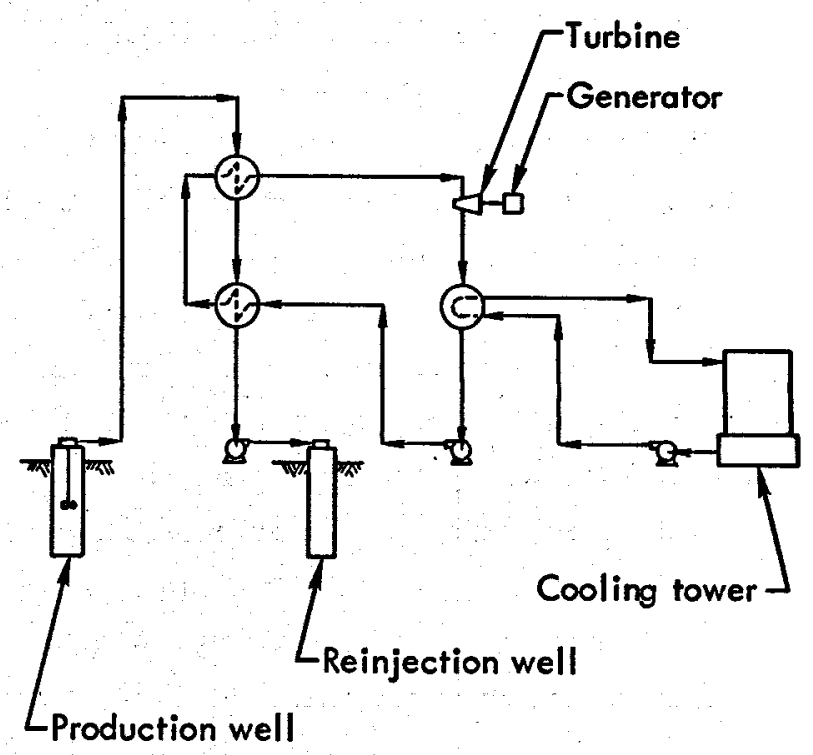

Fig. 22. Schematic of binary process for geothermal power generation.

performance. Heber fluids have much lower salinity than Salton Sea fluids (about $10 \%$ of the total dissolved solids); therefore, direct heat-exchanger operations may be feasible with Heber fluids. 


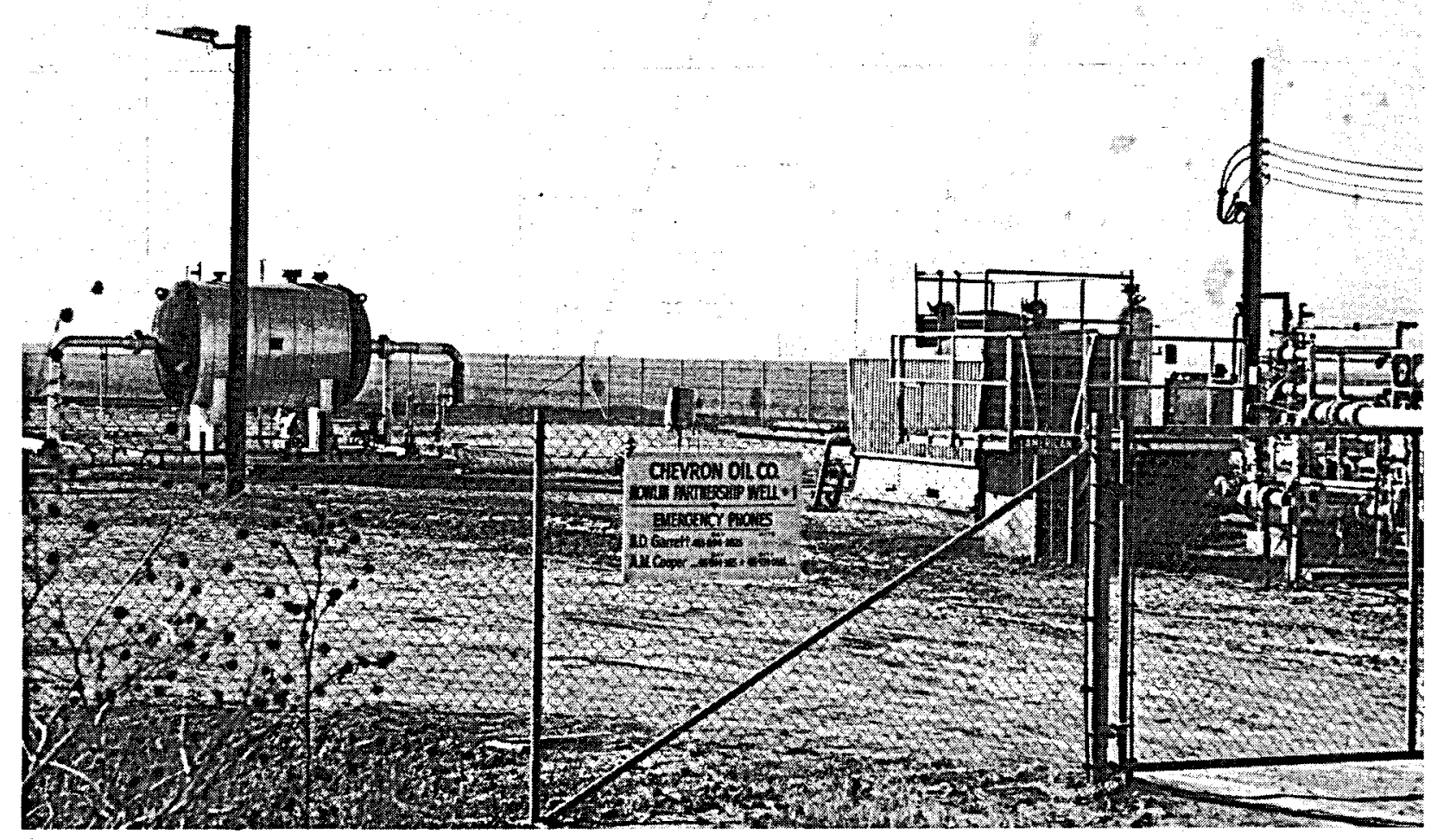

Fig. 23. Chevron Oil Company geothermal test site, Heber area, Imperial Valley, California.

\section{SALTON SEA GEOTHERMAL FIELD}

Wells in the Salton Sea geothermal area usually encounter hot water $\left(150\right.$ to $300^{\circ} \mathrm{C}$ ) between 300 and $1500 \mathrm{~m}$ below the surface. The concentration of solids in this water generally is 20 to $30 \mathrm{wt} \%$. About $20 \%$ of the water flashes into a steam-water mixture as it flows up the well pipe, leaving a highly concentrated salt brine. These conditions impose severe drilling and production problems on any attempt to exploit the resource. Although large volumes of heated, highly mineralized water are now known to exist in this area, commercial exploitation has been largely unsuccessful primarily due to the highly corrosive nature of the brines plus the problems of residual-salt disposal. In other respects, however, reservoir characteristics are attractive enough to encourage ventures to overcome these obstacles. The reservoir occupies an estimated $65 \mathrm{~km}^{2}$, and sustained production yields for the few wells tested have reached $227,000 \mathrm{~kg} / \mathrm{hr}$ of brine. Such energy potential, located close to large population centers, has maintained interest in this geothermal area. Some of the more ambitious attempts to develop Salton Sea resources are summarized in the following subsections.

Imperial Thermal Products - Morton IID Wells*

Early in 1965, Imperial Thermal Products (ITP), a subsidiary of Morton International, Inc., contracted with various

\footnotetext{
*Thomas D. Palmer, Earth Sciences Division, Lawrence Livermore Laboratory, Livermore, CA.
} 
geothermal well owners in the Salton Sea area to investigate the technical problems associated with the commercial use of geothermal brines. The ensuing ITP research and development program focused on two areas:

- Process steam for power generation

- Process brine for mineral extraction.

A $3,000-\mathrm{kW}$ s.team-operated power plant was constructed at IID well \#1, and solar evaporation ponds were located nearby (Fig. 24). Token amounts of electrical power were generated and delivered to the local Imperial Irrigation District. However, brine-salt carryover in the steam phase caused severe scaling and corrosion of the turbine blades and auxiliary equipment. Power generation was eventually discontinued for further research into the scaling problem.

Two different techniques were considered for mineral recovery. One, steam

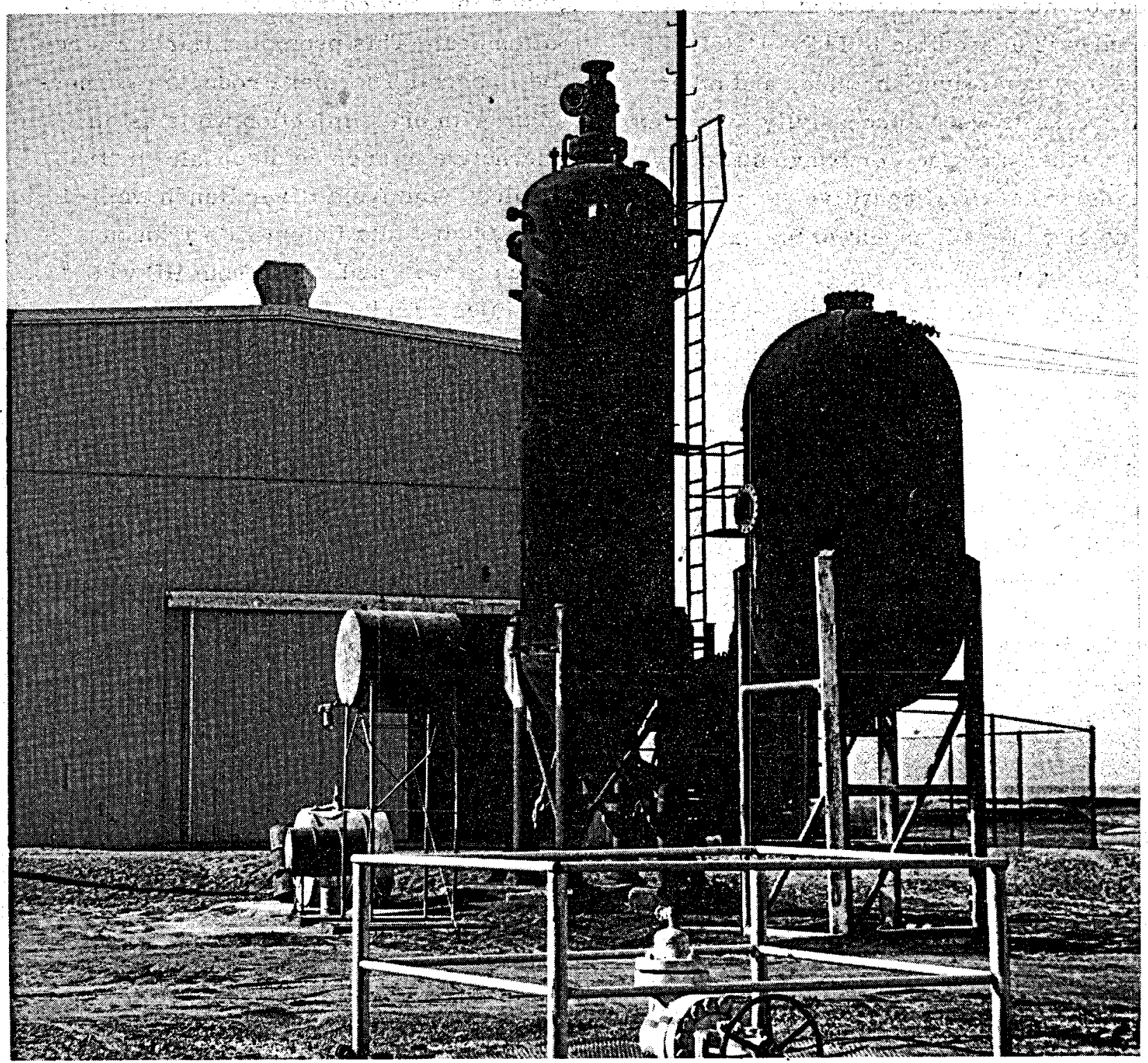

Fig, 24. Imperial Thermal Products, Inc.. Morton IID Well \#1, Imperial Valley, California. (Photo courtesy of Morton International, Inc.) 
and super-heated brine could be processed through vacuum pans to precipitate out recoverable minerals, with the steam then being used for power generation. Or, two steam could be flashed from the brine and the brine then discharged into open ponds, where marketable minerals could be concentrated by solar evaporation and fluid leaching. The second method was selected for full-scale testing because of its lower production cost and greater steam yield. Much of the original research and development of mineral extraction and harvesting methods is accredited to ITP. Calcium chloride, potassium chloride, and other mineral salts were successfully extracted and marketed by the Company until declining prices of competitive sources eventually brought an end to the extraction venture.

Other ITP research efforts included: reservoir characterization, brine production and control, brine content analysis, and reinjection techniques. The ITP site is no longer in operation, but it still represents the first successful attempt at generating electrical power using Salton Sea geothermal brines.

Earth Energy Company-River Ranch Well \#1

In 1964-65, Earth Energy Company (a subsidiary of Union-Pure Oil Co.) located a geothermal pilot plant at the River Ranch well \# 1 in the Niland area (Fig. 25). Solar evaporation ponds were constructed on adjoining property, and a pilot separation plant was erected at the well. Attempts to produce electrical

"Thomas D. Palmer, Earth Sciences Division, Lawrence Livermore Laboratory, Livermore, CA. power and extract minerals from the brine met with limited success. Operation of the wells ultimately shifted to Union Oil, who expanded research operations temporarily and then discontinued the Niland operation in favor of the Brawley geothermal area. Union presently plans to drill four exploratory wells in the Brawley area.

In 1963, the Colorado River Basin Regional Water Quality Control Board prohibited the discharge of any geothermal brines into any channel draining into the Salton Sea. This prompted Earth Energy and Imperial Thermal Products to experiment with brine injection wells as an alternative to surface disposal. In 1965 , surplus brine from River Ranch well \#1 was injected into Union Oil's Hudson Ranch well \#1 and brine from IID well \#1 was injected into Morton's IID well \#3. Reinjection is now generally considered to be the best method of waste-brine disposal and continues to be an area of active research.

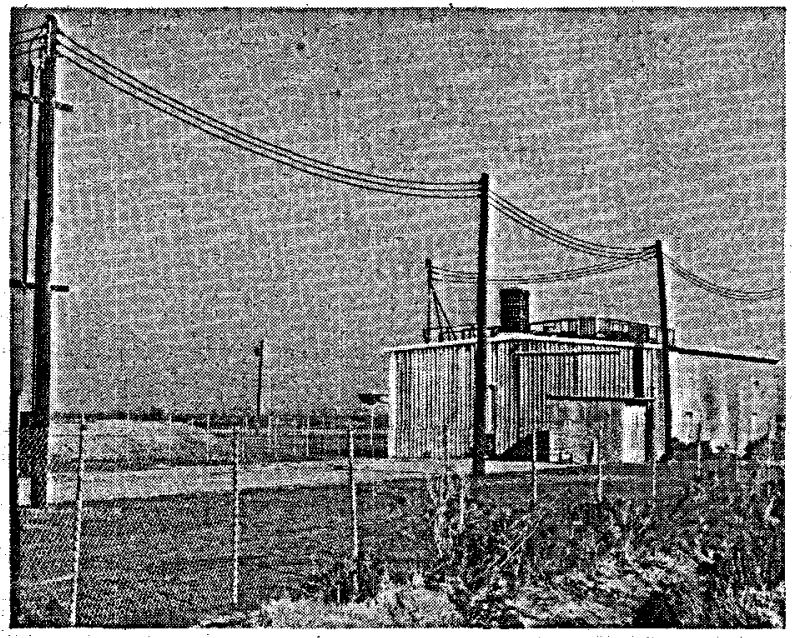

Fig. 25. Earth Energy Company's geothermal well River Ranch \#1, Imperial Valley, California. 
Phillips Petroleum Company - Sinclair Wells *

The Sinclair wells (located on the Sinclair Ranch) are among the earliest efforts to exploit the Salton Sea's geothermal resources. Sinclair well \#4 and 77 acres of solar evaporation ponds (Figs. 26 through 28) were used as early as 1966 by the Chloride Products Company, Inc., and Western Geothermal, Inc., to produce calcium chloride, Operations were later conducted by Hills Brothers, and presently are in charge of Lee Chemical.

\footnotetext{
* B. W.. Berthelot, Phillips Petroleum Company, San Diego, CA.
}

The current Sinclair-wells geothermal operation was organized in 1972 , as a joint venture of the Southern Pacific Land Company, Southern California Edison Company, and Phillips Petroleum Company. The basic plan of this joint research and development program is to:

- Establish a reliable, continuous, geothermal brine production and injection disposal system

- Investigate scaling and corrosion problems and develop methods to minimize them

- Perform studies aimed at utilizing geothermal brines for power production.

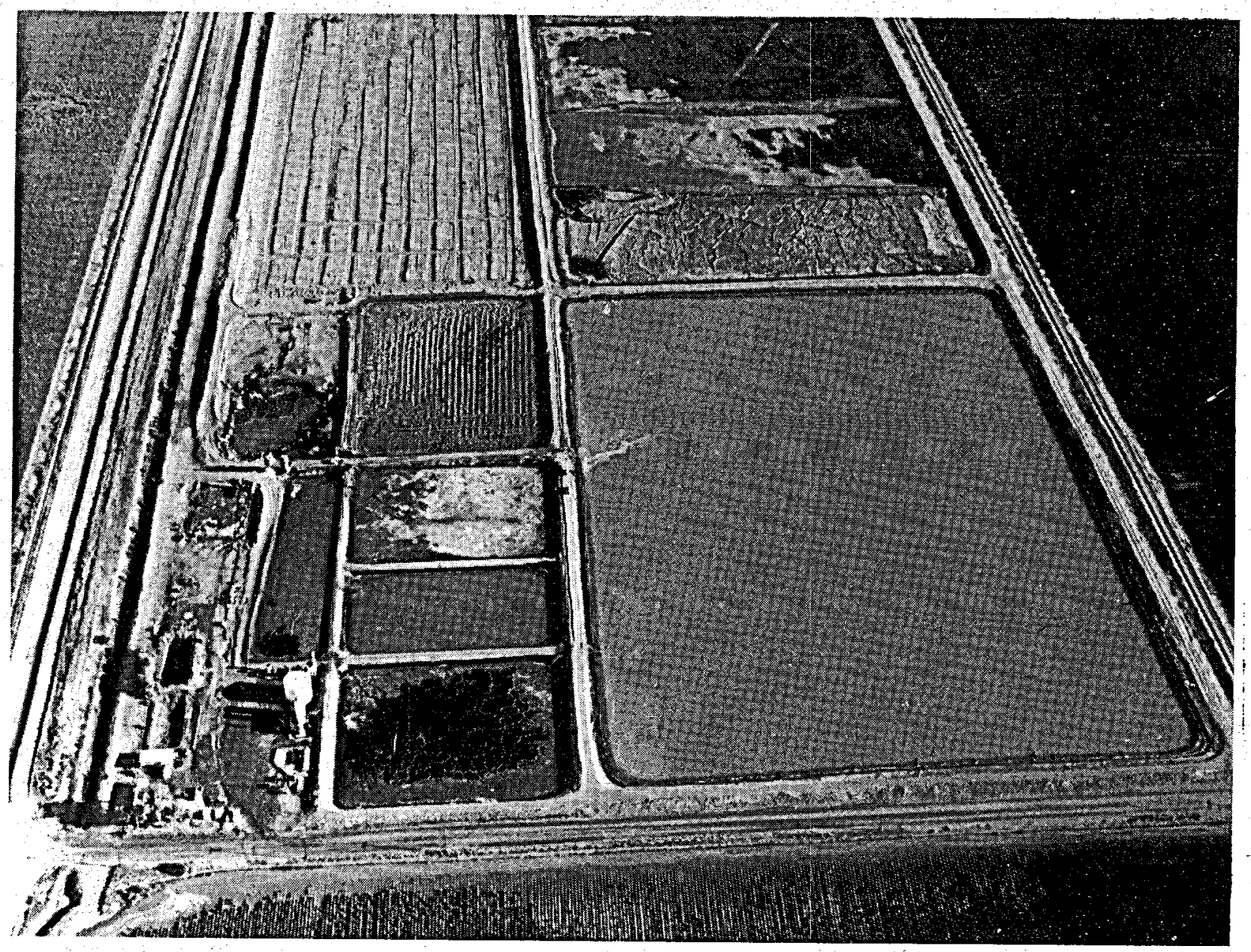

Fig. 26. Phillips Petroleum Company geothermal well Sinclair \#4, Imperial Valley, California. 


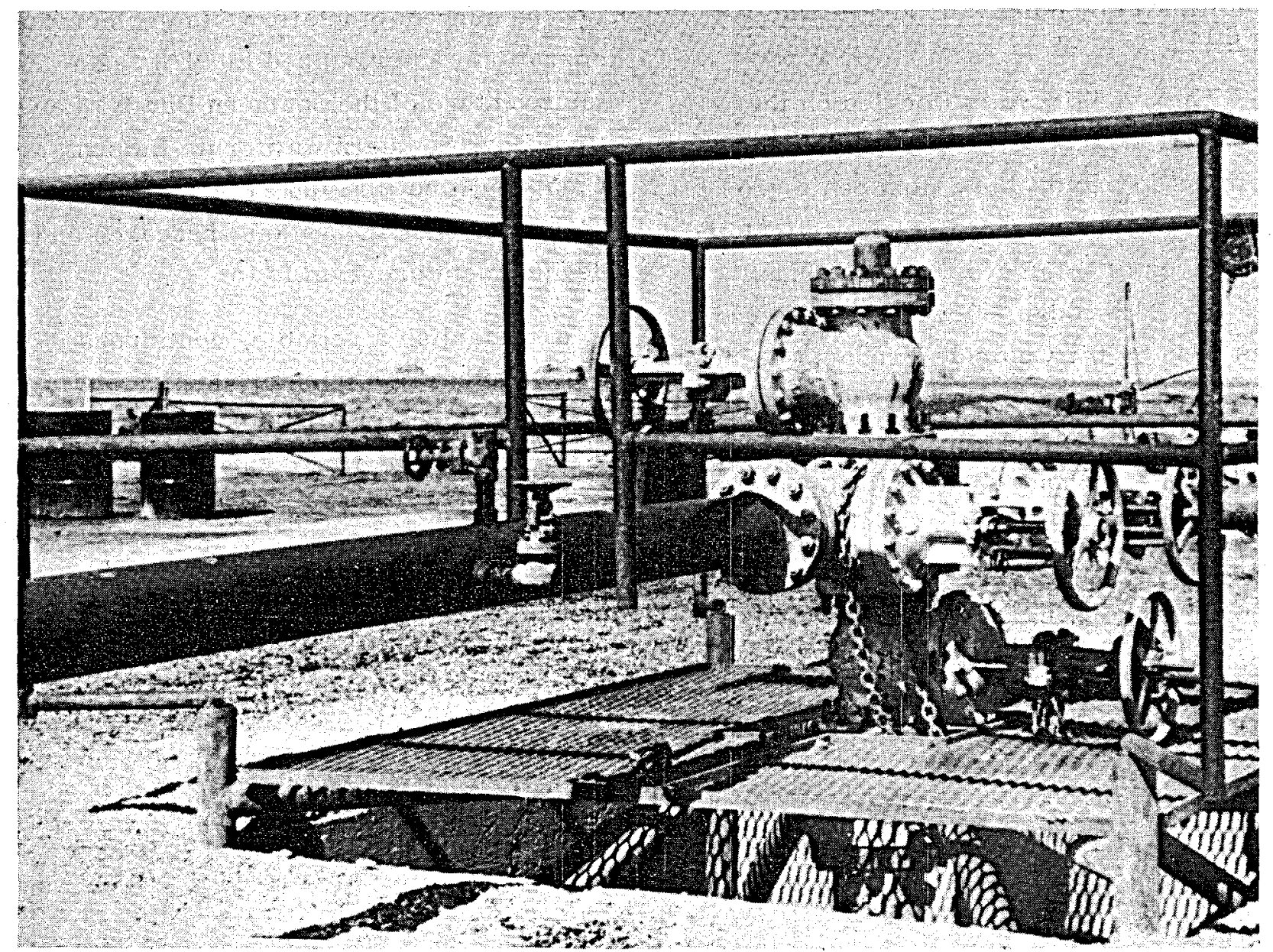

Fig. 27. Wellhead, geothermal well Sinclair \#4, Imperial Valley, California.

With these goals in mind, two of the

Sinclair wells were reconditioned and an

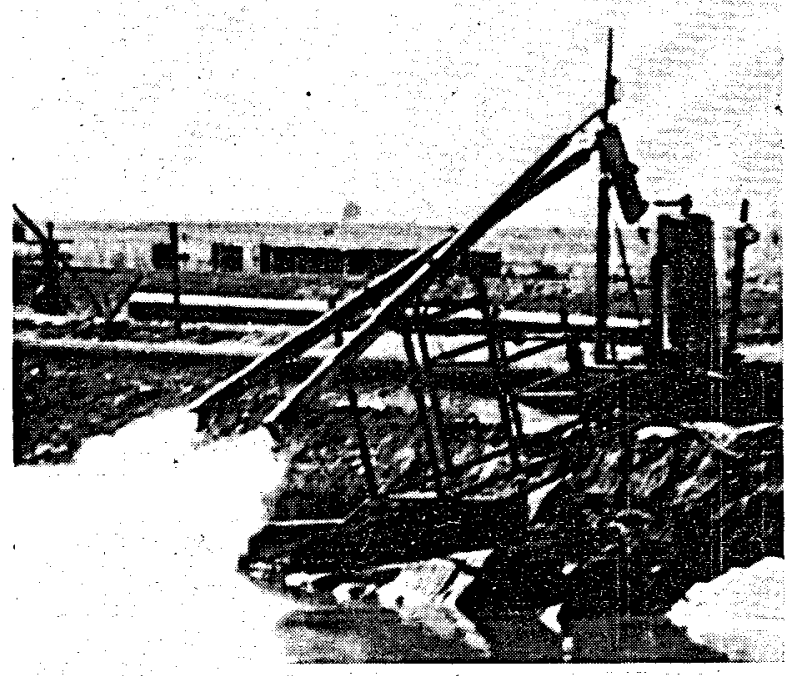

Fig. 28. Test site, geothermal well Sinclair \#4, Imperial Valley, California. inter-well fluid line was designed, installed, and tested. Three periods of well flow have been completed to establish the nature of the fluids, determine well characteristics, identify hydraulicmechanical relationships, and conduct dynamic system tests. This operation is still underway, and an expanded program is planned.

San Diego Gas and Electric Company-Magma Power Company Wells ${ }^{*}$

San Diego Gas and Electric (SDG\&E) entered the geothermal arena in 1971.

\footnotetext{
Thomas C. Hinrichs, Magma Power Company, Los Angeles, CA.
} 
Two factors contributed heavily to this action. First, was the realization that the availability of low-cost natural gas to fuel power plant boilers was diminishing rapidly. And second, was the fact that work underway in the Imperial Valley by U. C. Riverside, under the sponsorship of the U.S. Bureau of Reclamation, was demonstrating a potential geothermal resource within an economic distance of the Company's service area (San Diego County and a portion of southern Orange County).

The Utility actually became involved in geothermal activities through an agreement with its wholly-owned resource subsidiary, New Albion Resources Company (NARCO) and the Magma Power Company and Magma Energy, Inc. The agreement provided that, in return for funding drilling and testing on Magma leases in the Imperial Valley, NARCO could obtain an interest in the leases.

During early 1972, exploratory drilling was conducted in several areas of the Valley to identify geothermal sites for development. The most promising locations were the Niland area, at the south end of the Salton Sea, and the Heber area, south of the town of El Centro. A second well was drilled in each of these areas to confirm initial findings and to provide reinjection capability for flow testing.

Flow testing was carried out at the Niland site in mid 1972, using a large wellhead separator on loan from the Union Oil Company. The test provided information on well deliverability, fluid characteristics, and other information necessary to design a geothermal test facility to evaluate the feasibility of power generation from the resource.
In August 1972, the C. F. Braun Company was contracted to design and procure major equipment for a geothermal test facility. The facility was designed on the binary system, using a single steam flash, with the steam and brine from the flash tank being directed through heat exchangers that, in turn, heated isobutane. This facility was completed in early 1973. An area of uncertainty in the design was the longevity of the brine exchangers. Therefore, the Braun Company decided to run some small-scale field tests prior to starting construction of the geothermal test facility.

During 1973, a small-scale test facility was constructed and installed at the Niland site. A flow diagram of the 1973 test hardware is shown in Fig. 29. Fluids from the producing well entered the sep- arator at 150 psig. Steam from the top of the separator passed through one heat exchanger, and brine leaving the bottom of the separator flowed through another heat exchanger. Both steam and brine temperatures were about $190^{\circ} \mathrm{C}$. Mineral content of the geothermal brine was approximately $200,000 \mathrm{ppm}$. Concentrations of solids in the steam leaving the test separator ranged from 40,000 to $80,000 \mathrm{ppm}$. In both the steam and brine exchangers, heat transfer performance declined from an initial value to design limits after some $100 \mathrm{hr}$ of operation (due to scaling). Testing continued until the fall of 1973; however, a satisfactory solution was not found for mitigating the brine and steam scaling problem. Therefore, construction of the large geothermal test facility was delayed.

In early 1974, work resumed to develop effective methods for separating steam from geothermal brine and scrubbing the 


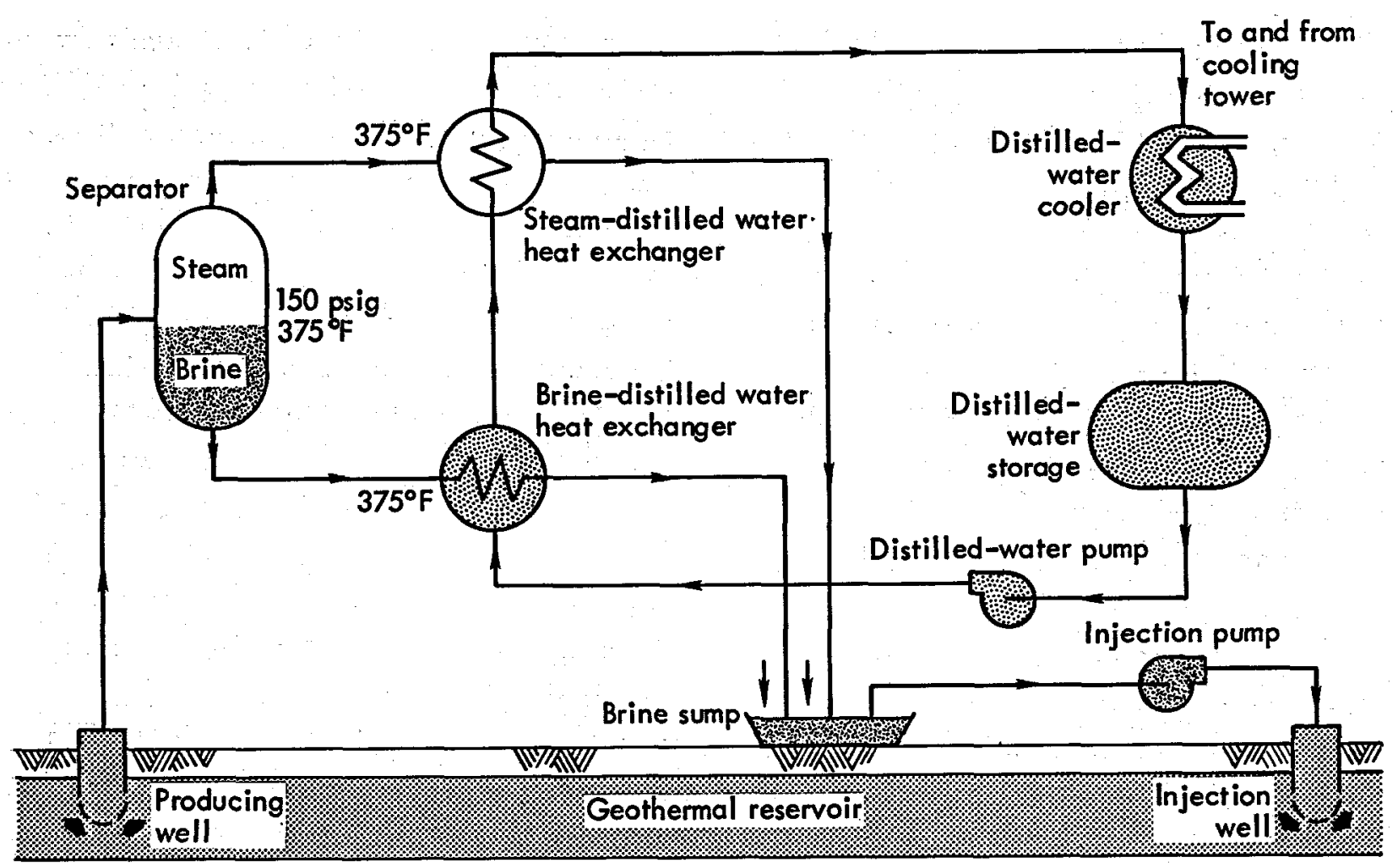

Fig. 29. Schematic of 1973 geothermal field test system: heat exchanger system, San Diego Gas and Electric Company. (Figure courtesy of SDG\&E.)

steam to achieve as pure a product as possible. Brine heat-exchanger testing was discontinued. Figure 30 shows a flow diagram of the 1974 test apparatus. These tests, completed during the summer of 1974, consisted of passing steam through separators, scrubbers, and heat exchangers to determine if scrubbing the steam would eliminate the severe scaling problems.

The first phase of the 1974 test program consisted of evaluating different types of steam separators. The separator selected yields outlet steam with a solids content of approximately $200 \mathrm{ppm}$, a considerable reduction from the initial well fluid solids content of $200,000 \mathrm{ppm}$. Figure 31 is a cutaway view of the separator, showing the interior of the vessel. Both the firststage (150 psig) and second-stage (50 psig) separators have the same configuration.
Well fluid enters the separator through the port in the bottom left side of the chamber and impinges on the vessel end dome, where a plate protects the vessel wall. Steam leaves the separator through a port in the upper right corner of the vessel. Brine collects at the bottom of the separator then flows to the second-stage unit through the port in the lower right corner of the vessel.

The interior of the steam scrubber is shown in Fig. 32. Steam from the separator enters the scrubber through the lower left-hand port. It then flows upward through five trays of pure water, which scrubs solids out of the steam. The cleaned steam then exists at the top of the scrubber. Wash water is added continuously to the scrubber through the top of the vessel, cascading down to exit drains 


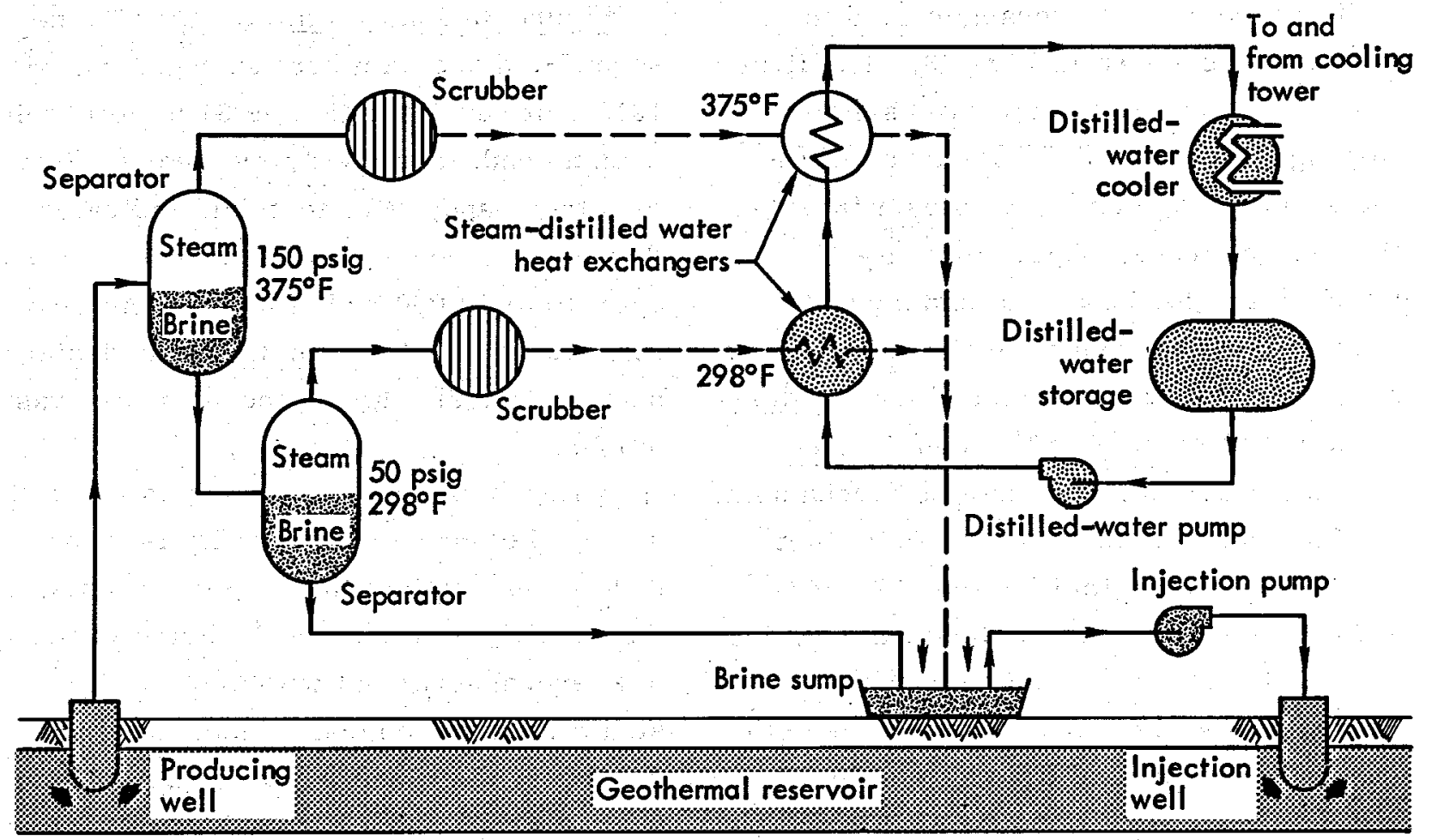

Fig. 30. Schematic of 1974 geothermal field test system: two-stage flash system, San Diego Gas and Electric Company. (Figure courtesy of SDG\&E.)

at the bottom. During the 1974 test, solids content in the scrubbed steam ranged from 10 to $20 \mathrm{ppm}$, compared to the 100 to $200 \mathrm{ppm}$ entering the scrubber from the separator.

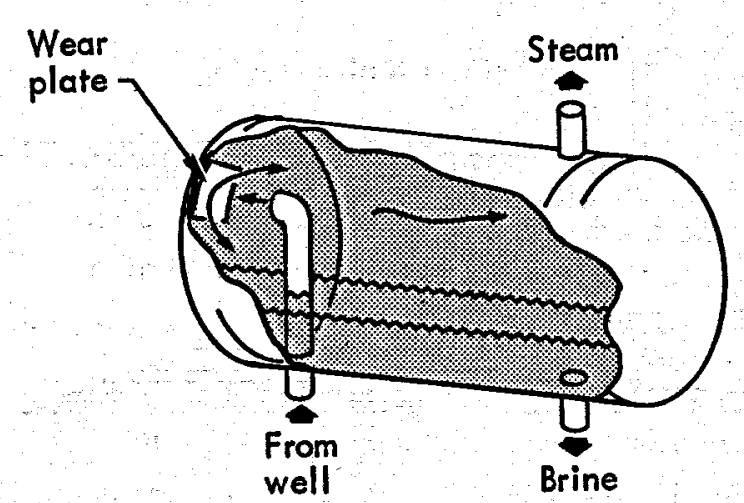

Fig. 31. C.F. Braun scale-model separator, 1974 field test, San Diego Gas and Electric Company. (Figure courtesy of SDG\&E.)

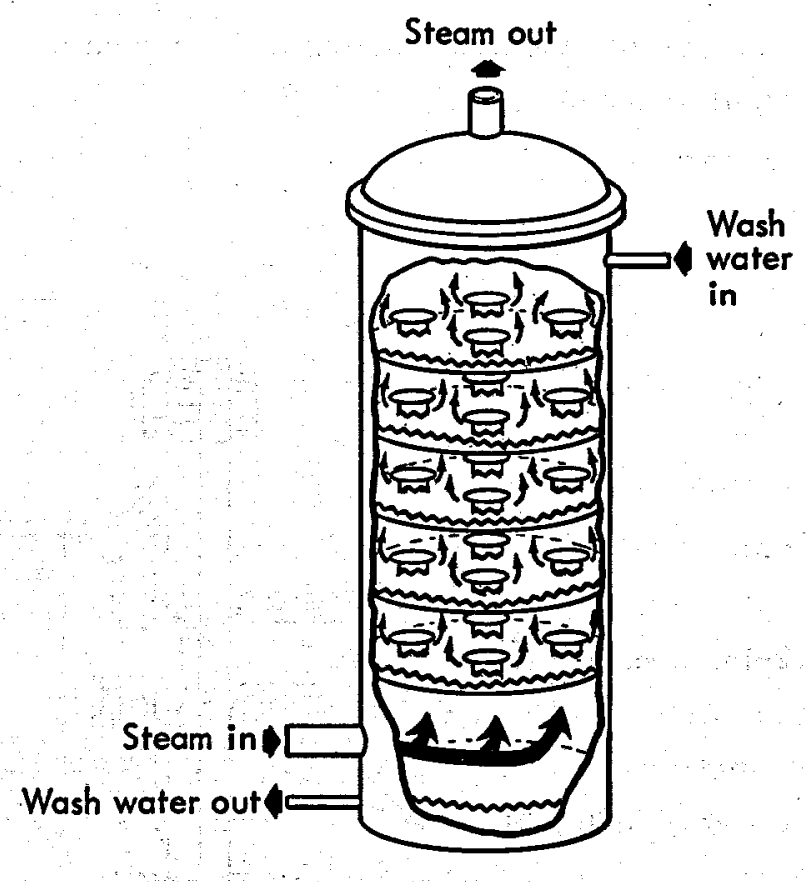

Fig. 32. Ben Holt steam scrubber, 1974 field test, San Diego Gas and Electric Company. (Figure courtesy of SDG\&E.) 
The type of heat exchanger used in the 1974 tests is shown in Fig. 33. The firststage heat exchanger employed steam flowing on the outside of the tubes while the second-stage unit used steam flowing through the tubes. Approximately $454 \mathrm{~kg} /$ $\mathrm{hr}$ of steam (for both first and second stages) flowed through the heat exchangers and was condensed. A closed loop of distilled water circulated through the heat exchanger provided the cooling mechanism.

The overall heat transfer coefficient versus operating time for the 1973 and 1974 first-stage tests is shown in Fig. 34. The 1974 test results indicate that the heat exchangers will operate for $3,200 \mathrm{hr}$ before reaching design conditions requiring cleanup, an encouraging improvement over the $108 \mathrm{hr}$ required to reach cleanup conditions in the 1973 tests. Total operating time for the first-stage heat exchanger during the 1974 test was $398 \mathrm{hr}$, sufficient time to establish a trend on which to predict the number of operating hours before cleanup would be required.
Figure 35 shows similar data for the second-stage steam heat exchangers. Here, 1973 test results indicated $81 \mathrm{hr}$ to reach design conditions requiring cleanup. On the other hand, 1974 test data indicates that the second-stage heat exchangers will operate to $10,050 \mathrm{hr}$ before needing cleaning. Operating time for the second-stage heat exchangers during the 1974 test was $587 \mathrm{hr}$.

A flow diagram of the anticipated, fullscale, geothermal test facility is shown in Fig. 36. Unlike the two-stage tests, this facility will not use the brine in the heat exchangers, but will flash it into steam in three stages. Then, after passing through scrubbers, the steam will be routed through heat exchangers to heat an isobutane working fluid that, in turn, will be used to power a turbine generator. After use, the steam will be recondensed, combined with residual brine, and discharged through reinjection wells. The Ben Holt Company has been contracted by SDG\&E to do the necessary redesign work

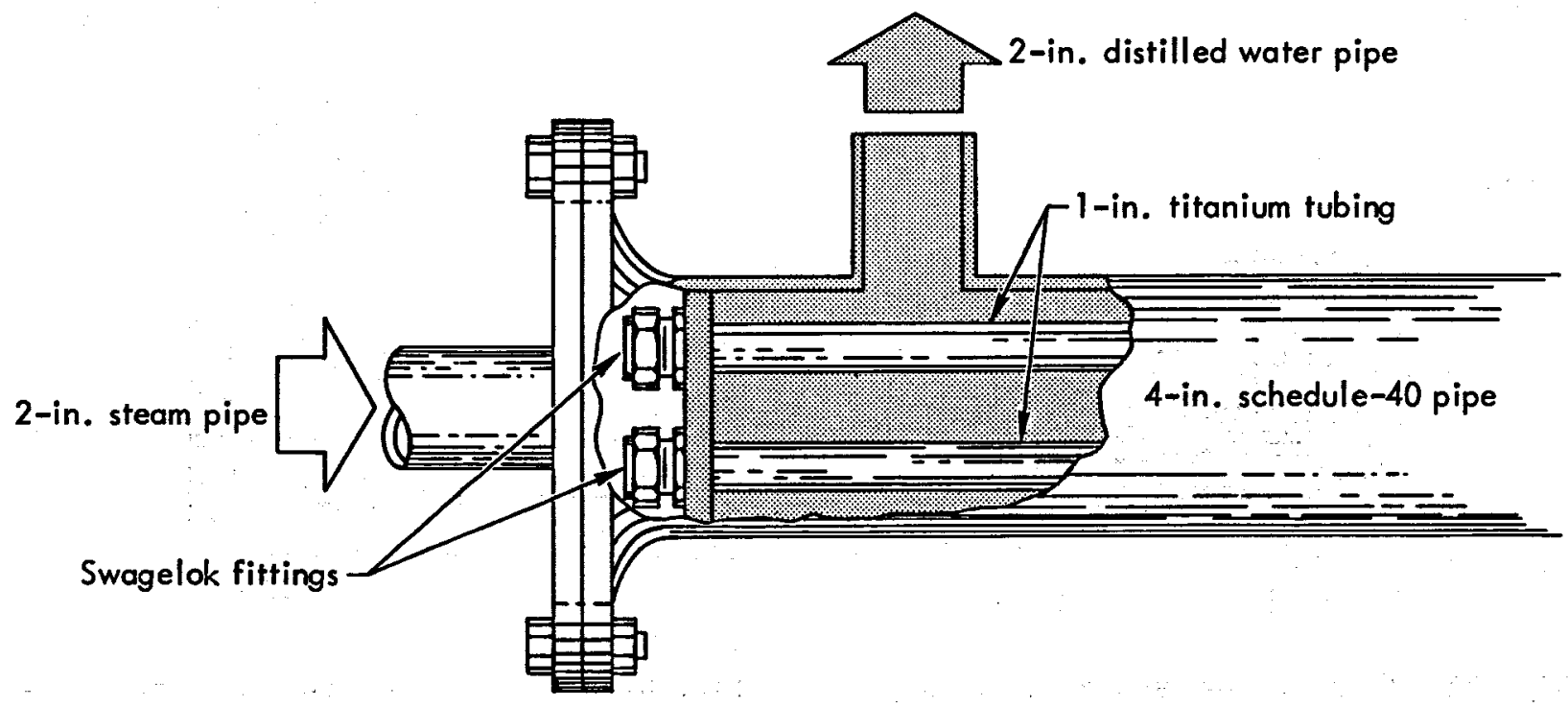

Fig. 33. Heat exchanger, 1974 field test, San Diego Gas and Electric Company. (Figure courtesy of SDG\&E.) 


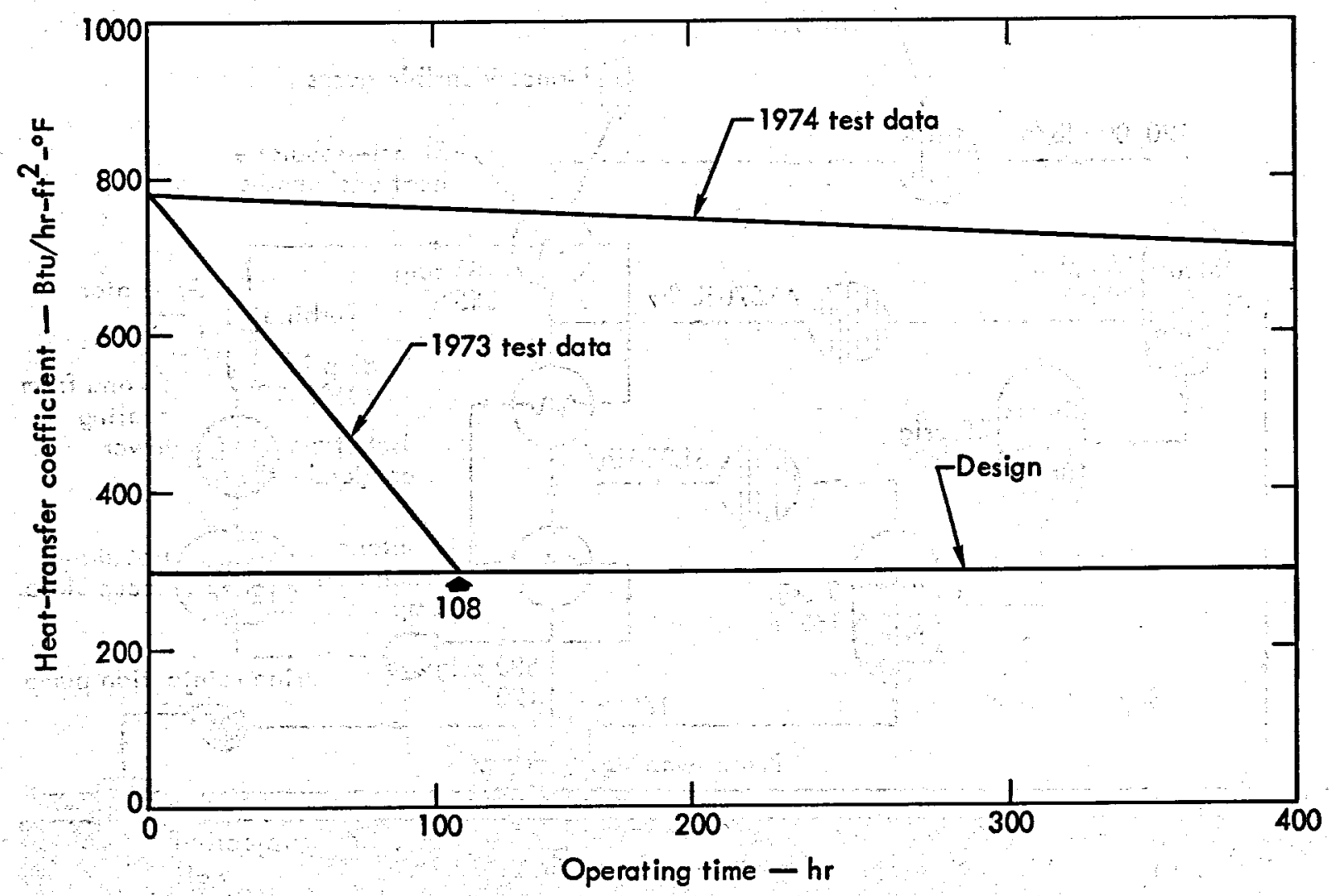

Fig. 34. First-stage heat exchanger tests, San Diego Gas and Electric Company. (Figure courtesy of SDG\&E.)

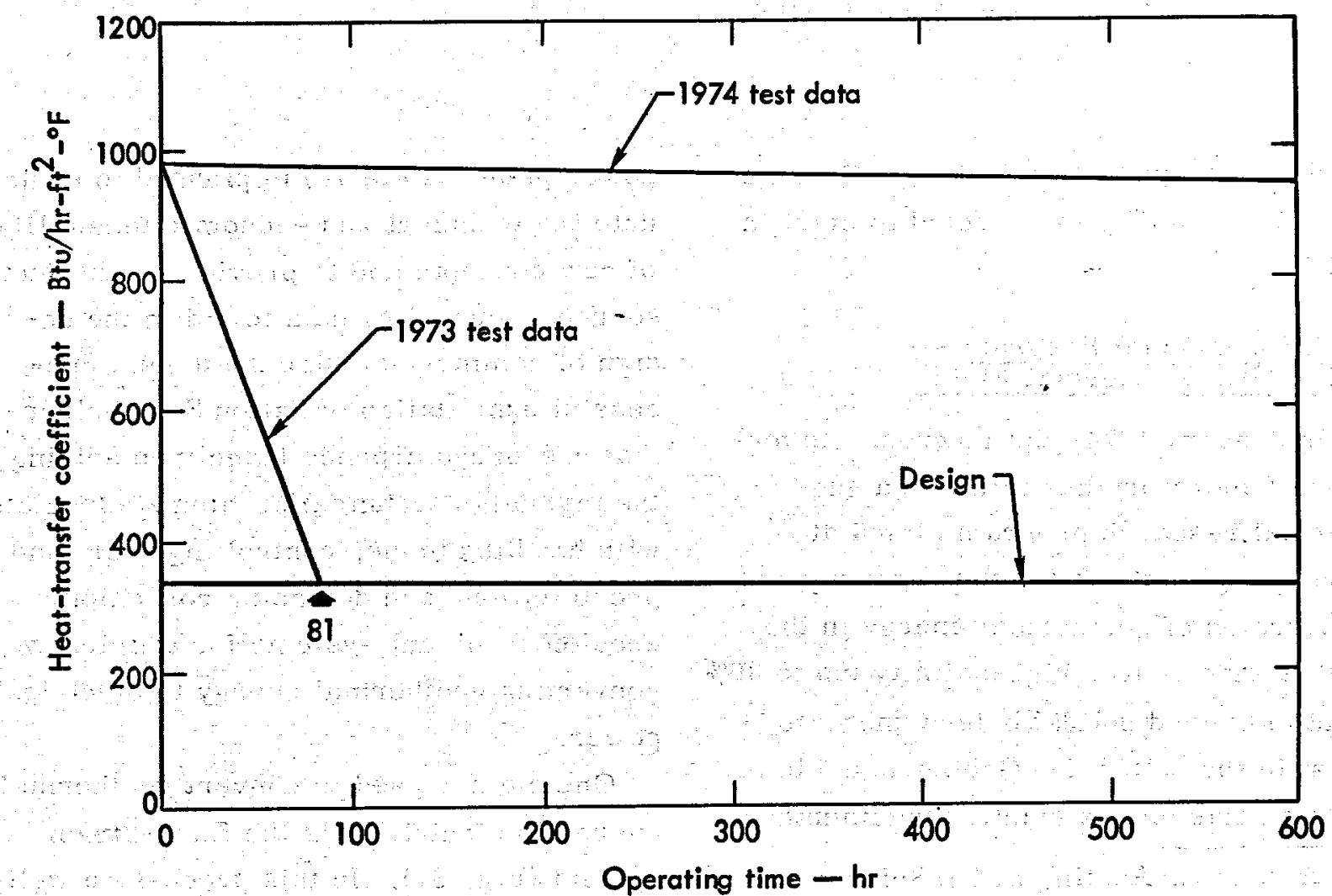

Fig. 35. Second-stage heat exchanger tests, San Diego Gas and Electric Company. (Figure courtesy of SDG\&E.) 


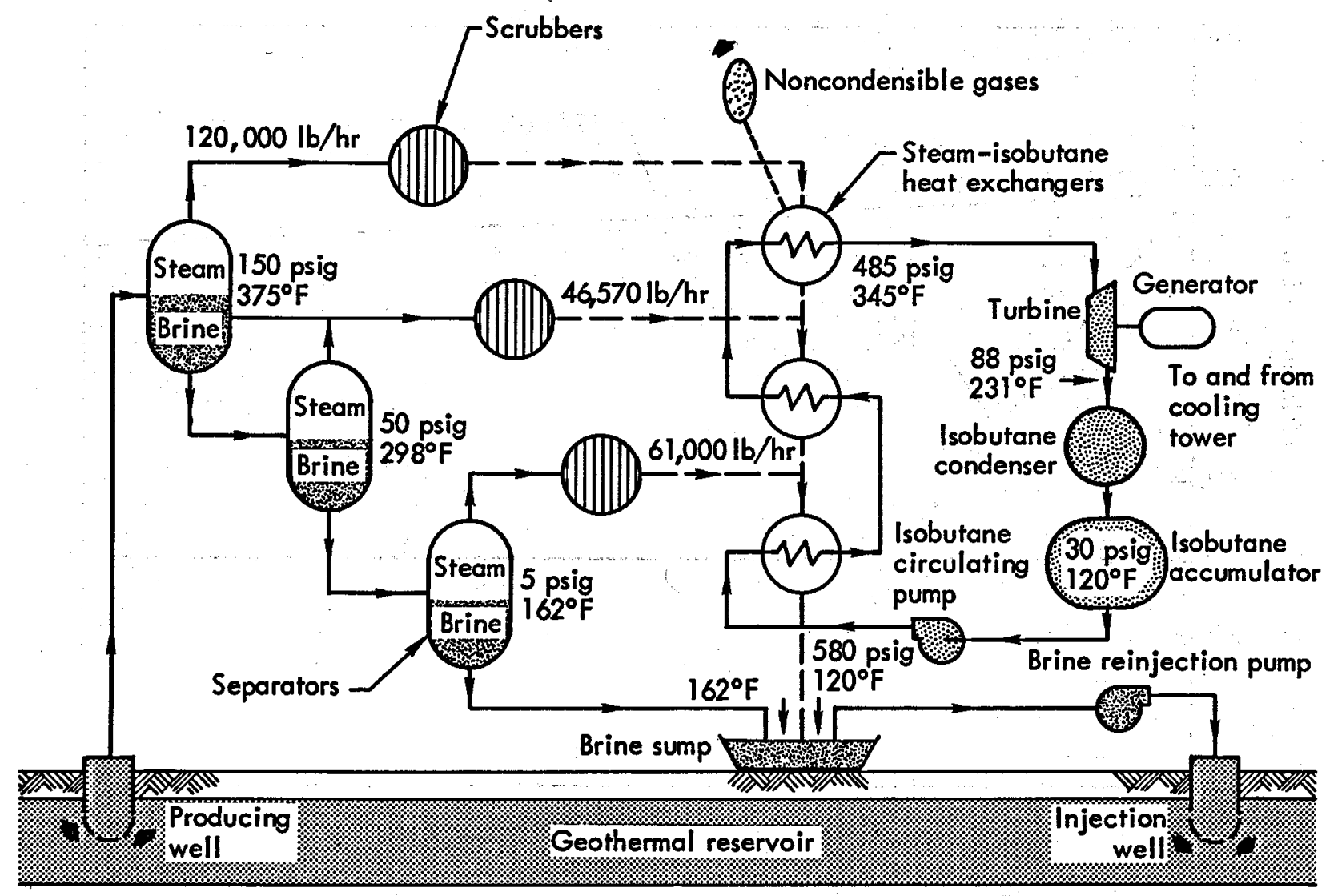

Fig. 36. Three-stage steam flash system, San Diego Gas and Electric Company. (Figure courtesy of SDG\&E.)

on the geothermal test facility. Construction of the facility is expected to start in 1975.

LLL Geothermal Program-
Salton Sea Geothermal Field

In January 1974, the Lawrence Livermore Laboratory has initiated a geothermal research program aimed at developing methods for the recovery and conversion of geothermal energy in the high-temperature, high-salinity (up to $30 \%$ total dissolved solids) brines known to exist in the Salton Sea Geothermal Field. Toward this end, a small experimental

*Arthur L. Austin, Earth Science Division and Anders W. Lundberg, Energy Systems Engineering Division, Lawrence Livermore Laboratory, Livermore, CA. power plant $(<10 \mathrm{MWe})$ is planned to evaluate the technical and economic feasibility of new concepts and to provide a continuing source of operating data to aid in the design of commercial-size systems. Successful exploitation of Salton Sea geothermal resources depends largely on solving the myriad of technical problems associated with handling brine, controlling scale and precipitation, and designing corrosion/ erosion-resistant systems for efficiently converting geothermal energy to electrical power.

One method used to convert geothermal energy to electricity is the flash-steam system (Fig. 37). In this process, a wellhead mixture of hot water and steam is piped into separators where the steam 


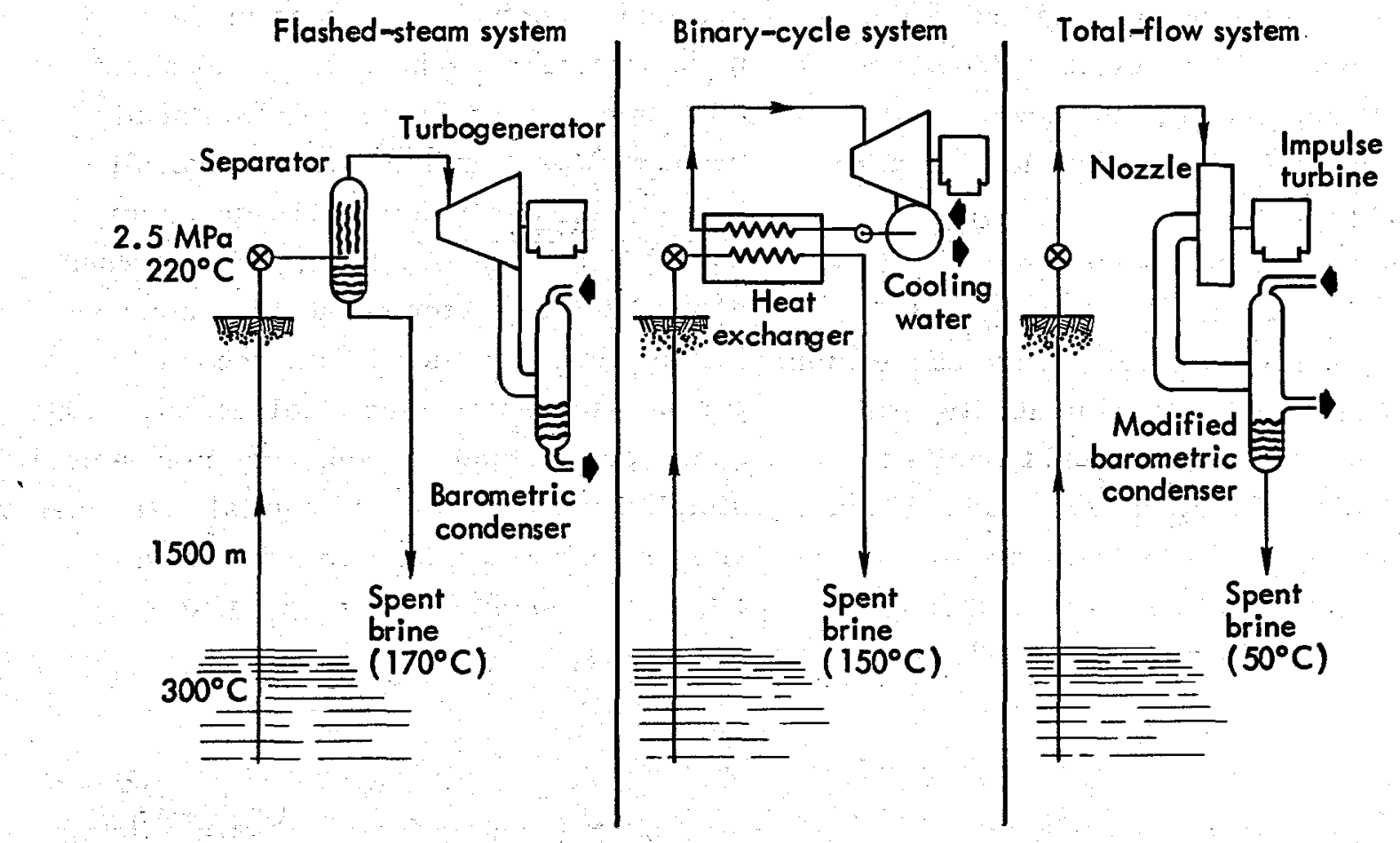

Fig. 37. Methods for electric power generation from hot-water deposits.

fraction is separated from the liquid. The saturated steam, then, is used to drive standard multistage turbines, and the remaining hot liquid is discarded. How ever overall thermal efficiency of this process, using brines at 260 to $315^{\circ} \mathrm{C}$, is only about $11 \%$. Moreover, the flashsteam method generally is limited to lowsalinity water $(<2 \%)$. With higher-salinity brines, salt carryover in the steam causes scaling in the separator.

In an attempt to solve these difficulties and to provide a more thermally efficient conversion process, a binary-cycle system (Fig. 37) is being developed in the geothermal industry. This system uses a heat exchanger to transfer the thermal energy to a clean, low-boiling-point fluid that, in turn, is used to drive a conventional turbine. To prevent flashing and scaling in the heat exchanger, a downhole pump is being considered. This system probably will have about the same thermal efficiency as the flash system for brine deposits at 260 to $315^{\circ} \mathrm{C}$. Better downhole pumps and more corrosion- and scale-resistant heat exchangers are necessary before this sys tem can be applied commercially to highsalinity waters.

Since past research has shown the problems of scale deposition to be severe, LLL proposes an entirely different approach - the Total Flow System (Fig. 37; Austin, et al., 1973). In principle, this system consists of passing the total, hot, wellhead, brine-steam mixture directly through a mixed-phase expander to drive a turbine and electrical alternator. One scheme is to expand the wellhead mixture through converging-diverging nozzles to convert fluid enthalpy into kinetic energy in the form of high-velocity jets, which can be used to drive a specially designed impulse turbine similar to hydroelectric 
turbines. The important feature is that all pressure and temperature drop in the fluid will take place in the nozzles, allowing the turbine to operate at low temperature and pressure.

This concept offers the potential advantages of inherent mechanical and thermodynamic simplicity, high conversion efficiencies, and design flexibility, which facilitates scale control and permits a wider choice of materials. Also, by confining pressure and temperature drop to a single component (the nozzles) there is greater opportunity for brine treatment and scale control. Successful development of this concept could yield about $60 \%$ more power output per wellhead product (i.e., an increase in overall thermal efficiency from $11 \%$ to about 18\%). This is especially significant when applied to lower-temperature resources, in that fewer wells will be needed to produce the same electrical output. Because of this and the inherent mechanical simplicity of the system, capital investments and power costs should be lower than either flash-steam or binary-cycle processes.

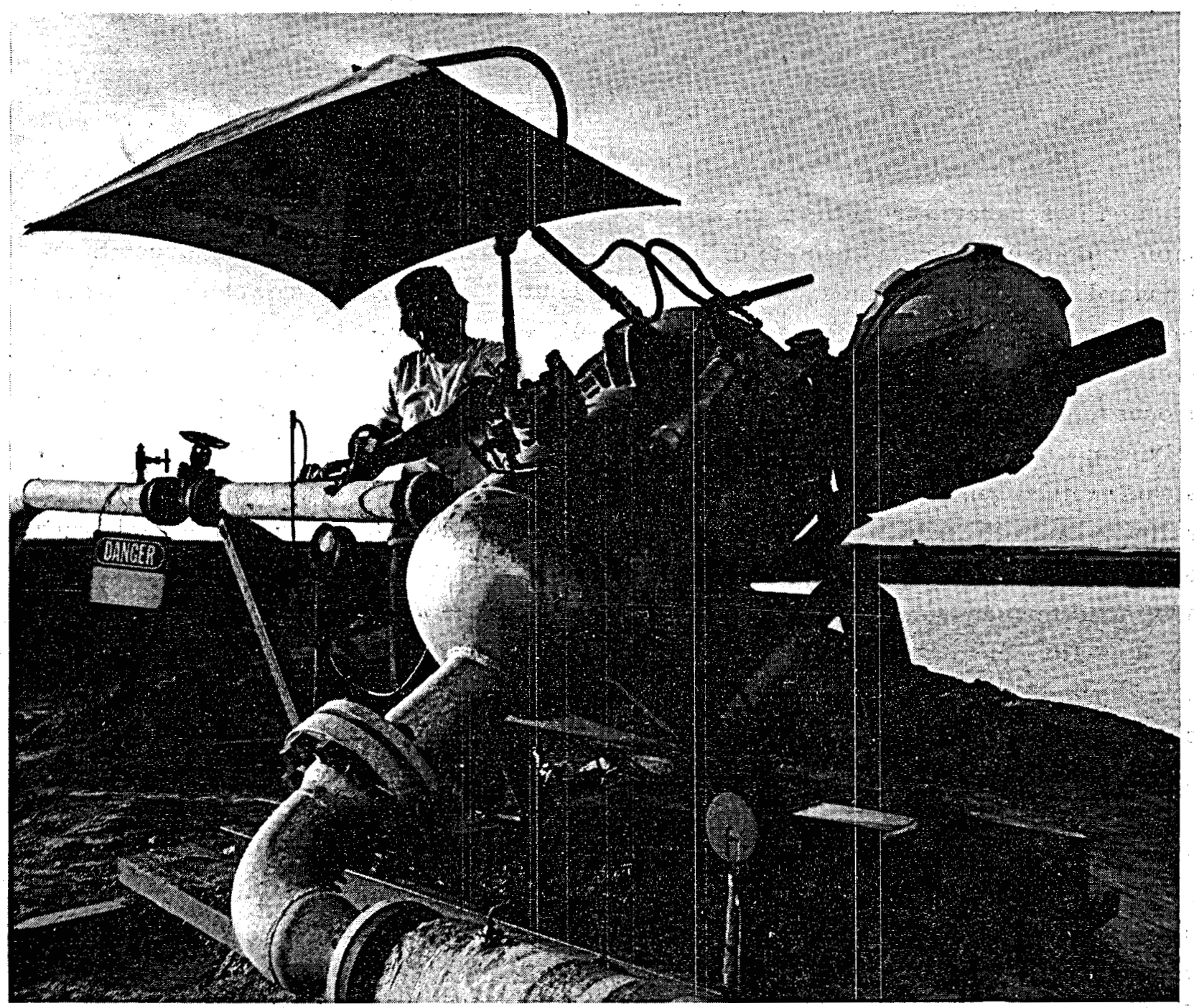

Fig. 38. Lawrence Livermore Laboratory field material test chamber, well Sinclair \#4, Imperial Valley, California: 


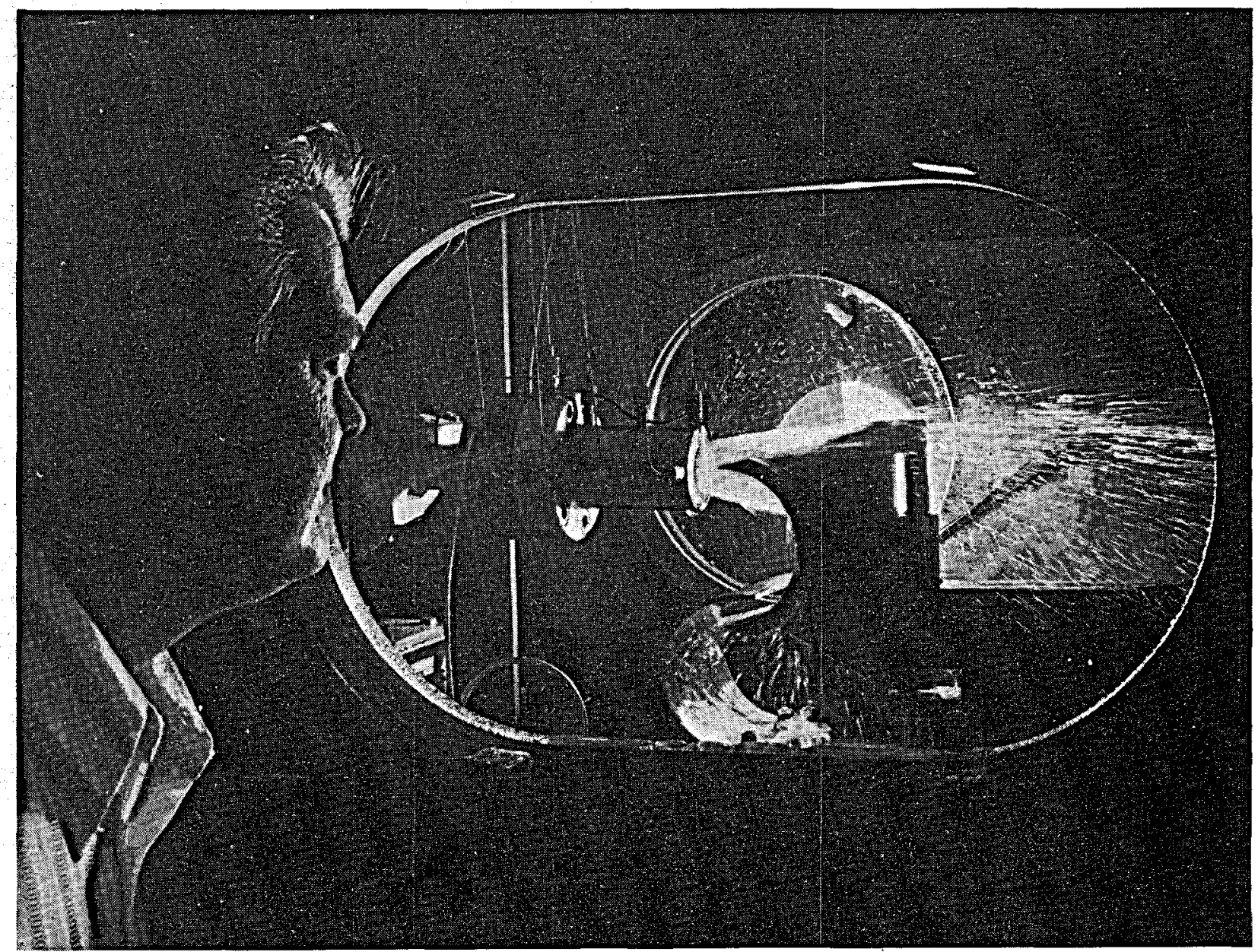

Fig. 39. Lawrence Livermore Laboratory turbine test chamber, Livermore California.

In summary, the aim of the LLL geothermal program is to develop the technology necessary to convert hightemperature, high-salinity geothermal brines into useable electrical power. Toward this end, major emphasis is on:

- Designing, testing, and evaluating energy-conversion concepts

- Analyzing brine chemistry and developing effective scale- and corrosion-control methods

- Identifying brine-tolerant materials and fabrication methods for geothermal applications

- Building and operating a smallscale geothermal power plant based on the Total Flow process.
The goal is to resolve most of the key technical issues by mid 1977 so that design of a 10-MWe demonstration system can begin that year. Completion and test of this pilot facility is scheduled for 1979. To date, progress in the LLL program includes: development of analytical methods for well flow characterization, initial studies of turbine configurations, construction of bench-model turbines, completion of a preliminary evaluation of the Salton Trough resource, analyses of typical scales taken from wells in the area, construction and operation of a field test chamber for preliminary materialscreening and nozzle-performance tests (Fig. 38), and completion of a laboratory 

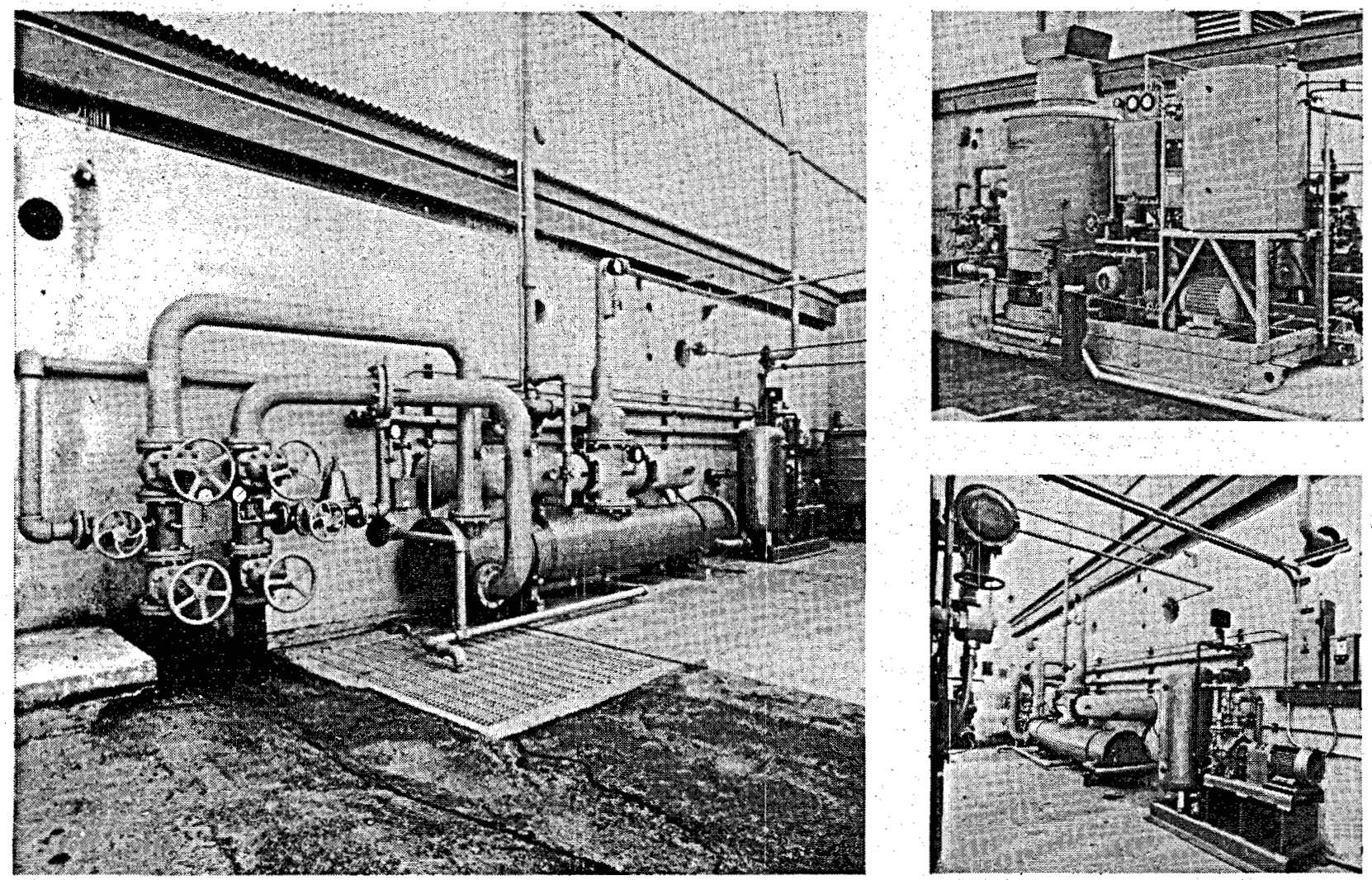

Fig. 40. Lawrence Livermore Laboratory turbine test facility, Livermore, California.

for testing the performance of turbines, nozzles, and other components (Figs. 39 and 40). The performance-test facility consists of a.water heater capable of producing about $0.7 \mathrm{~kg} / \mathrm{sec}$ of $300^{\circ} \mathrm{C}$ saturated water at 1400 psia. By throttling to lower pressure, a range of thermodynamic characteristics typical of wellhead condi- tions can be reproduced. The facility also includes a cooling system to allow turbine operation at backpressures as low as $12 \mathrm{kPa}$. The facility will be used for laboratory testing and performance evaluation of Total Flow concepts up to $100-\mathrm{kw}$ capacity, prior to field testing. 


\section{References}

A. L. Austin, G.H. Higgins, and J.H. Howard, The Total Flow Concept for Recovery of Energy from Geothermal Hot Brine Deposits, Lawrence Livermore Laboratory, Rept. UCR L-51366 (1973).

T. Atwater, "Implications of Plate Tectonics for the Cenozoic Evolution of Western North America," Geol. Soc. Amer. Bull, 81, 3513 (1970).

E.A. Babcock, "Detection of Active Faulting Using Oblique Infrared Aerial Photography in the Imperial Valley of California," Geol. Soc. Amer. Bull. 82, 3189-3196 (1971).

S. Biehler, R. L. Kovach, and C. R. Allen, Geophysical Framework of Northern End of Gulf of California Structural Province, Amer. Assoc. Petro. Geol. Memo No. 3, pp. 126-143 (1964).

D.K. Bird, Geology and Geochemistry of the Dunes Hydrothermal System, Imperial Valley of California (unpublished thesis), University of California, Riverside, p. 121 (1975).

S. W. Carey, in Continental Drift (Geology Dept. Symposium, University of Hobart, Australia, 1970), pp. 177-355.

J. Combs and D. Hadley, "Microearthquake Investigation of the Mesa Geothermal Anomaly, Imperial Valley, California," Geophys. 39.

J. C. Crowell, "Tectonics and Sedimentation," in Soc. of Economic Paleontologists and Mineralogists Spec. Pub. No. 22, W. R. Dickinson, Ed., pp. 190-204 (1974).

T. W. Dibblee, Jr., "Geology of the Imperial Valley Region, California," in Geology of Southern California, R.H. Jahns, Ed., Calif, Div. Mines, Bull. 170, vol. 1, pp. 21-28 (1954).

L. C. Dutcher, W. F. Hardt, and W.R. Moyle, Jr., Preliminary Appraisal of Ground Water in Storage in the Imperial Valley Area, California, U.S. Geol. Survey Circular 659, p. 57 (1972).

W. A. Elders and S. Biehler, "Gulf of California Rift System and Its Implication for the Tectonics of Western North America," Geology 3, No. 2, p. 85 (1975).

W. A. Elders and D.K. Bird, "Investigations of the Dunes Anomaly, Imperial Valley, California: Part 2. Active Formation of Silicified Caprocks in Arenaceous Sands in a Low-Temperature Geothermal Environment, in the Salton Trough of California, U.S.A.," in Proc. Symposium on Waterrock Reaction, 1974 (International Union of Geochemistry and Cosmochemistry, Prague, 1974).

W. A. Elders, R.W. Rex, T. Meidav, P.T. Robinson, and S. Biehler, "Crustal Spreading in Southern California," Science 178, 15-24 (1972).

A. Griscom and L. J.P. Muffler, Aeromagnetic Map and Interpretation of the Salton Sea Geothermal Area, California, U.S. Geol. Survey, Geophys. Invest. Map GP 754 (1971).

H. C. Helgeson, "Geologic and Thermodynamic Characteristics of the Salton Sea Geothermal System," Amer. Journ. Soil 266 (No. 3), 129-166 (1968). 
R. L. Larson, "Bathymetry, Magnetic Anomalies, and Plate Tectonic History of the Mouth of the Gulf of California," Geol. Soc. Amer. Bull. 83, 3345-3360 (1972).

R. L. Larson, H.W. Menard, and S. M. Smith, "Gulf of California: A Result of Ocean Floor Spreading and Transform Faulting," Science 161, 781-784 (1968).

C. Lomnitz, F. Mooser, C. Allen, J.N. Brune, and W. Thatcher, "Seismicity of the Gulf of California Region, Mexico-Preliminary Results," Geofis. Int. 10, 37 (1970).

T. Meidav and R. Ferguson, "Resistivity Studies of the Imperial Valley Geothermal Area, California," Geothermics 1, 47-62 (1972).

R. Merriam and O. L. Bandy, "Source of Upper Cenozoic Sediments in Colorado Delta Region," Jour. Sed. Pet. 35 (No. 4), 911-916 (1965).

D. G. Moore,"Plate Edge Deformation and Crustal Growth, Gulf of California Structural Province," Geol. Soc. Amer. Bull. 84, 1883 (1973).

L. J.P. Muffler and B.R. Doe, "Composition and Mean Age of Detritus of the Colorado River Delta in the Salton Trough, Southeastern California," Journ. Sed. Petrology 38 (No. 2), 384-399 (1968).

L. J.P. Muffler and D.E. White, "Active Metamorphism of Upper Cenozoic Sediments in the Salton Sea Geothermal Field and the Salton Trough, Southeastern California," Geol. Soc. Amer. Bull. 80, 157-182 (1969).

W. Randall, "Percent Volume Sand Bodies in the Imperial Valley," in R. W. Rex, et al., Cooperative Geological-Geophysical-Geochemical Investigations of the Geothermal Resources in the Imperial Valley Area of California; Final report (FY 1971), Contr. No. 14-06-300-2194, U.S. Bureau of Reclamation (1971).

W. Randall, An Analysis of the Subsurface Structure and Stratigraphy of the Salton Sea Geothermal Anomaly, Imperial Valley, California, Ph.D. dissertation, University of California, Riverside (1974).

R. W. Rex, Investigation of Geothermal Resources in the Imperial Valley and Their Potential Value for Desalination of Water and Electricity Production, Inst. Geophys. and Planetary Phys., University of California, Riverside, Rept. 92502 (1970).

R.W. Rex, E. A. Babcock, S. Biehler, J. Combs, T. B. Coplen, W. A. Elders, R. B. Furgerson, Z. Garfunkel, F. Meidav, and P. F. Robinson, Cooperative Geological-Geophysical-Geochemical Investigations of Geothermal Resources in the Imperial Valley Area of California, Inst. Geophys, and Planetary Phys., University of California, Riverside (1971).

R. W. Rex, S. Biehler, J. Combs, T. B. Coplen, R. B. Furgerson, Z. Garfunkel, F. R. Getts, J.P. Mass, and M. Reed, Cooperative Investigation of Geothermal Resources in the Imperial Valley Area and Their Potential Value for Desalting of Water and Other Purposes, Inst. Geophys. and Planetary Phys., University of California, Riverside, Rept. 72-33 (1972).

P.T. Robinson, W.A. Elders, and L.P.J. Muffler, "Holocene Volcanism in the Salton Sea Geothermal Field, Imperial Valley, California," Geol. Soc. Amer. Bull. (in press). 
D.P. Sigurdson, T. Meidav, and R,V. Sharp, "Structure and Sediments Under the Salton Sea," Geol. Soc. Amer. Abst. 3, 192 (1971).

G. Sykes, The Colorado River Delta, Carnegie Inst.,. Washington, D.C., Pub. No. 460 (1937).

W. Thatcher and J. N. Brune, "Seismic Study of An Ocean Ridge Earthquake Swarm in the Gulf of California," Geophys. J. R. Asr. Soc. 22, 473-489 (1971).

R.W. Thompson, Tidal Flat Sedimentation on the Colorado River Delta, Northwestern Gulf of California, Geol. Soc. Amer; Memo 107 (1968).

P. C. Van De Kamp, "Holocene Continental Sedimentation in the Salton Basin, California: A Reconnaissance," Geol. Soc. Amer. 84, 827-848 (1973).

J.T. Wilson, "A New Class of Faults and Their Bearing on Continental Drift," Nature 207, 343-347 (1965).

G. D. Woodward, "Redefinition of Cenozoic Stratigraphic Column in Split Mountain Gorge, Imperial Valley, California," Amer. Assoc. Petrol. Geol. Bull. 58 (No. 3), 521 (1974).

$\mathrm{WOS} / \mathrm{md} / \mathrm{la}$ 


\section{Selected Bibliography}

A. L. Austin and A. W. Lundberg, A Comparison of Methods for Electric Power Generation from Geothermal Hot Water Deposits, ASME, 74-WA/Ener-10 (1974).

E. H. Alonso, "La Zona Geothermica de Cerro Prieto, Baja California," Bol. Soc. Gebl. Mex. 29, 17-47 (1966).

G. B. Bradshaw and W. W. Donnan, Groundwater Investigations of Imperial County, California, U.S. Dept. Agriculture Soil Conservation Service Report, Los Angeles (1952).

Geothermal Wastes and the Water Resources of the Salton Sea Area, California Dept. of Water Resources, Bull. 143-7, p. 123 (1970).

H. Craig, "Isotopic Composition and Origin of the Red Sea and Salton Sea Geothermal Brines," Science 154, 1544-1548 (1966).

H. Craig, "Source Fluids for the Salton Sea Geothermal System (Discussion)," Amer. Jour. Sci. 267, 249-255 (1969).

W. A. Elders and P.T. Robinson, "Possible Sea-floor Spreading in the Imperial Valley of California IV: A Model for Magma Generation (Abst.);" EOS Trans. Amer. Geophys. Union 51, No; 4 (1970).

W.A. Elders, T. Meidav, R.W. Rex, and P.T. Robinson, "The Imperial Valley of California: The Product of Oceanic Spreading Centers Acting on a Continent," Geol. Soc. Amer. Abst. 2 (No. 7), 545 (1970).

D. K. Grubb, Ore Bearing Magmatic and Metamorphic Brine from the Salton Sea Volcanic Domes Geothermal Area, Imperial County, California (M.S. thesis), University of Virginia (1963).

W. Hamilton, "Origin of the Gulf of California," Geol. Soc. Amer. Bull. 72, 1307-1318 (1961).

T. L. Henyey and J. G. Sclater, "Heat Flow in the Northern Gulf of California (Abst.)," Geol. Soc. Amer. (Cordilleran Sect.), Riverside, Calif. Program, pp. 135-136 (1971).

P.H. Jones, "Geothermal Resources of the Northern Gulf of Mexico Basin," Geothermics (Spec. Issue 2) 2 (pt. 1), 14-26 (1970).

T. Keith, E.C. Muffler, L. J. Patrick, and M. Cremer, "Hydrothermal Epidote Formed in the Salton Sea Geothermal System, California," Amer. Mineralogist 53 , 1635-1644 (1968).

V.C. Kelley and J. L. Soske, "Origin of the Salton Volcanic Domes, Salton Sea, California," Jour. Geol. 44, 496-509 (1936).

J. B. Koenig, The Salton-Mexicali Geothermal Province, Calif. Div. Mines \& Geol., Mineral Info. Serv., vol. 20, No. 7, pp. 75-81 (1967).

C. R. Longwell, "History of the Lower Colorado River and the Imperial Depression," in Geology of Southern California, R. H. Jahns, Ed., Calif. Div. Mines Bull. 170, vol. 1, pp. 53-56 (1954). 
G. S. Mercado, "High-Activity Hydrothermal Zones Detected By Na/K, Cerro Prieto, Mexico," in Proc. of United Nations Symposium on the Development and Utilization of Geothermal Resources; Geothermics (Spec. Issue 2) 2 , pt. 2 (in press).

L. J.P. Muffler and D.E. White, "Origin of $\mathrm{CO}_{2}$ in the Salton Sea Geothermal System, Southeastern California, U.S.A.," in Proc. 23rd Internat. Geol. Cong., Prague, 1968, vol. 97, Symp. 2, pp. 185-194

E. Paredes, Salinity Map of the Mexicali Valley, Groundwater Division, Government of Mexico, Mexicali Branch (updated).

W. Randall, T. Meidav, R.W. Rex, and L. Coursey, "Electrical Resistivity and Geochemistry of Aquifers in the Durnival Dome, Imperial Valley (Abst.)," Amer. Geophys. Union Trans. 49 (No. 4), 759 (1968).

R. W. Rex, "Heat Flow in the Imperial Valley of California (Abst.)," Amer. Geophys. Union Trans. 74 (No, 1), 181 (1966).

R. W. Rex, "Geochemical Water Facies in the Imperial Valley of California (Abst.)," Amer. Geophys. Union Trans. 49 (No, 4), 758 (1968).

R.W. Rex, Investigation of the Geothermal Potential of the Lower Colorado River Basin: Phase 1-The Imperial Valley Project, Inst. Geophys. and Planetary Phys., University of California, Riverside (updated 1968).

R. W. Rex, Investigation of Geothermal Resources in the Imperial Valley and Their Potential Value for Desalination of Water and Electricity Production, in California Water, D. Seckler, Ed. (Univ. of Calif. Press, Berkeley, 1971), pp. 190-205.

P.T. Robinson and W.A. Elders, "Possible Sea Floor Spreading in the Imperial Valley of California III: Xenoliths in Rhyolite Volcanoes as Samples of the Basement (Abst.)," EOS Trans. Amer. Geophys. Union 51 (No. 4), 422 (1970).

B. J. Skinner, D.E. White, H. J. Rose, and R.E. Mays, "Sulfides Associated with the Salton Sea Geothermal Brine," Econ. Geol. ' 62 (No. 3), 316-330 (1967).

U.S. Bureau of Reclamation, Geothermal Resource Investigations, Imperial Valley, California: Status Report (1971).

U.S. Bureau of Reclamation, Geothermal Resource Investigations, Imperial Valley, California (1972).

R. P. Von Herzen, "Geothermal Heat Flow in the Gulfs of California and Aden," Science 140 1207-1208 (1963).

S. L. Werner and L. J. Olson, Geothermal Wastes and the Water Resources of the Salton Sea Area, Calif. Dept. Water Res., Bull. 143-7 (1970).

D. E. White and L. J.P. Muffler, Metamorphism of Upper Cenozoic Sediments to Greenschist Miner Assemblages, Salton Sea Geothermal Area, California (Abst.), Geol. Soc. America, Spec. Paper 32, pp. 221-222, 1965.

D. E. White, E.T. Anderson, and D. K. Grubbs, "Geothermal Brine Well: Mile-Deep Drill Hole May Tap Ore-Bearing Magmatic Water and Rocks Undergoing Metamorphism," Science 139, 919-922 (1963).

G. D. Woodard, "Stratigraphic Succession of the West Colorado Desert, San Diego and Imperial Counties, Southern California," Paper presented annual meeting

(Cordilleran Sect.). Geol. Soc. Amer., San Diego (1961). 